\title{
Sex significantly impacts the function of major depression-linked variants in vivo
}

\author{
Bernard Mulvey ${ }^{1}$, Din Selmanovic ${ }^{1}$, Joseph D. Dougherty ${ }^{2,3 *}$
}

\section{Affiliations:}

\author{
${ }^{1}$ Division of Biology and Biomedical Sciences, Washington University School of Medicine; \\ St. Louis, MO, USA 63110 \\ ${ }^{2}$ Department of Genetics, Washington University in St. Louis School of Medicine; St. Louis, \\ MO, USA 63110 \\ ${ }^{3}$ Department of Psychiatry, Washington University in St. Louis School of Medicine; St. \\ Louis, MO, USA 63110
}

*Corresponding author. Email: jdougherty@wustl.edu

Abstract: Genome-wide association studies have discovered blocks of common variants-likely transcriptional-regulatory - associated with major depressive disorder (MDD), though the functional subset and their biological impacts remain unknown. Likewise, why depression occurs in females more frequently than males is unclear. We therefore tested the hypothesis that riskassociated functional variants interact with sex and produce greater impact in female brains. We developed methods to directly measure regulatory variant activity and sex interactions using massively parallel reporter assays (MPRAs) in the mouse brain in vivo, in a cell type-specific manner. We measured activity of $>1,000$ variants from $>30$ MDD loci, identifying extensive sexby-allele effects in mature hippocampal neurons and suggesting sex-differentiated impacts of genetic risk may underlie sex bias in disease. Unbiased informatics approaches indicated that functional MDD variants recurrently disrupt sex hormone receptor binding sequences. We confirmed this with MPRAs in neonatal brains, comparing brains undergoing the masculinizing hormone surge to hormonally-quiescent juveniles. Our study provides novel insights into the influence of age, biological sex, and cell type on regulatory-variant function, and provides a framework for in vivo parallel assays to functionally define interactions between organismal variables like sex and regulatory variation.

One-Sentence Summary: Massively parallel assays in vivo identified extensive functional and sex-interacting common variants in depression risk loci.

\section{Main Text:}

\section{Introduction}

Major depressive disorder (MDD) is a profoundly disruptive and sometimes lethal

disorder, affecting women 2-3 times more frequently than men across countries and cultures (1). 
Sex differences are present across multiple levels of the disease, from symptom profiles (2) and effective drug classes (3) to brain-wide gene expression $(4,5)$. Genome-wide association studies(GWASes) have identified dozens of linkage regions each containing numerous singlenucleotide polymorphisms (SNPs) associated with MDD, demonstrating its heritability (6-8).

More recently, sex-by-genotype (SxG) analyses of large GWAS cohorts have revealed that MDD risk loci are for men and women, yet these loci explain up to 4-fold greater MDD heritability in females $(9,10)$. These findings suggest that sex interacts with a common pool of SNPs to attenuate or amplify the MDD risk they confer. However, disease-associated SNPs are seldom found in protein-coding space, complicating prediction of their molecular consequences. Instead, these SNPs are found in probable regulatory elements (REs), including transcriptional-regulatory sequences predicted from measures such as chromatin marks, accessibility, and conformation. Specific brain regions and cell types are enriched for such measures at — and in putative regulatory target genes of-MDD-associated loci, including the hippocampus $(7,11)$ and excitatory neurons (12-16), suggesting sites of action for these REs. In particular, there has been long-standing interest in the hippocampus regarding both MDD pathology and sex differences in the brain. Hippocampal volume reductions in MDD patients have been widely reported (17). Moreover, the hippocampus is subject to influences of sex from perinatal $(18,19)$ to adult life, presenting in MDD as sex differences in hippocampal volume loss (20) and gene expression (4).

Determining the identity of functional SNPs from MDD-associated regions is the first key step toward understanding the biological perturbations resulting from risk genotypes, which can in turn enable inference of dysregulated target genes and shared regulatory programs involved across loci. However, studies connecting MDD-associated SNPs to gene expression in brain tissue, even those that considered sex effects (21), have been limited to indirect and imperfect indicators of function (e.g., chromatin state), or confounded by linkage disequilibrium 
(e.g., for expression quantitative trait loci (eQTLs)). In contrast, direct measurement of regulatory output of common variants associated with disease has largely been restricted to the in vitro setting. The large-scale in vitro identification of functional regulatory variants has been made possible by massively parallel reporter assays (MPRAs), a method for functionally detecting activity from thousands of REs (and their variants) simultaneously. In brief, MPRAs adapt a traditional reporter assay paradigm — placing REs upstream of an optically measured reporter (e.g., luciferase) — but adds a unique, RE-identifying "barcode" sequence to the reporter's 3' untranslated region, enabling quantification of activity for thousands of REs simultaneously by RNA barcode sequencing. MPRAs have enabled identification of trait- and disease-associated SNPs affecting REs in culturable, disease-relevant cell types in vitro (22-25). However, the complexities of cell types interacting in the brain and of the sex hormonal milieu cannot readily be emulated ex vivo.

We overcome these prior limitations in functional regulatory SNP (rSNP) identification to interrogate the biological contexts under which MDD rSNPs act by delivering an MPRA library of MDD-associated variants (26) into the adult mouse hippocampus in vivo. Building on prior brain MPRAs of enhancers (27) and an RE variant (28), our approach greatly extends in vivo MPRA methods to identify rSNPs and their sex interactions, including those which are cell type-specific. First, we combined MPRA with translating ribosome affinity purification (TRAP) to simultaneously identify MDD rSNPs in both excitatory neurons and the broader hippocampus; these experiments utilized mice of both sexes, enabling us to additionally test the hypothesis that rSNPs are subject to sex-by-genotype $(\mathrm{SxG})$ interactions. Finally, to further characterize the potential role of circulating hormones in sex-differentiated rSNP activity, and to functionally replicate predicted fetal brain RE enrichments suggesting a role for MDD SNPs during circuit organization $(15,29-32)$, we likewise delivered the library to the mouse brain in utero. This 
allowed us to identify rSNPs neonatally, coinciding with a testosterone surge and critical period for establishing sex-specific brain circuitry (33), and test for loss of SxG effects in juveniles, when hormonal influences are quiescent. In sum, we illustrate that MPRAs can be leveraged in vivo to directly identify not only functional variants, but their context-dependence on age, sex, and cell type, while demonstrating that all three of these factors have substantial impacts on MDD-associated regulatory variation.

\section{$\underline{\text { Results }}$}

\section{Combining Translating Ribosome Affinity Purification (TRAP) with MPRAs}

REs in the brain, most recently in MPRA-like designs to screen multiple REs in parallel with RNA-seq-based quantification $(27,34,35)$. This suggests it may also be possible to adapt AAVMPRAs to study functional consequences of RE variants associated with disease. As MDD genetic risk is enriched in neuronal REs, we tested the feasibility of combining a cell typespecific profiling method, TRAP, with MPRA to attain measurements of RE activity specifically in neurons. We generated 4 small AAV9 libraries (Fig. 1A-C) expressing dsRed under the control of the hsp68 minimal promoter, with full-length human promoters (denoted $p G e n e$ ) with documented expression in neurons (human $p C A M K 2 A)$, astrocytes $(p G F A P)$, or all cells ( $p P G K 2$ ), each carrying unique 3' untranslated region (UTR) barcodes for quantification by RNA-seq. We first individually confirmed cell-type specificity by immunofluorescence (IF)

(Fig. 1D-F), and then delivered (36) a mixed pool of the four barcoded AAV9 libraries into the brain of postnatal day 2 (P2) neuron-specific TRAP mice (Snap25-Rpl10a-eGFP) (37). TRAP was then used to compare total brain and neuronal activity levels of the three promoters and the 
hsp68 promoter alone. We prepared MPRA sequencing libraries from 1) the delivered AAV pool (DNA), 2) total brain (input) RNA, and 3) TRAP (neuronal) RNA and assessed expression of each barcode by calculating a ratio of RNA counts to DNA counts. Results were highly replicable at the level of barcodes (Fig. 1G-H) in both RNA fractions. Moreover, neuronal TRAP fractions demonstrated increased expression of barcodes driven by $p C A M K 2 A$ and lower expression of $p G F A P$-paired barcodes (Fig. 1I). These results demonstrated that cell typespecific effects, even of relatively small magnitudes, can be detected using a combined MPRATRAP approach. We then turned to applying this method to test the effects of human variants associated with psychiatric disease. 


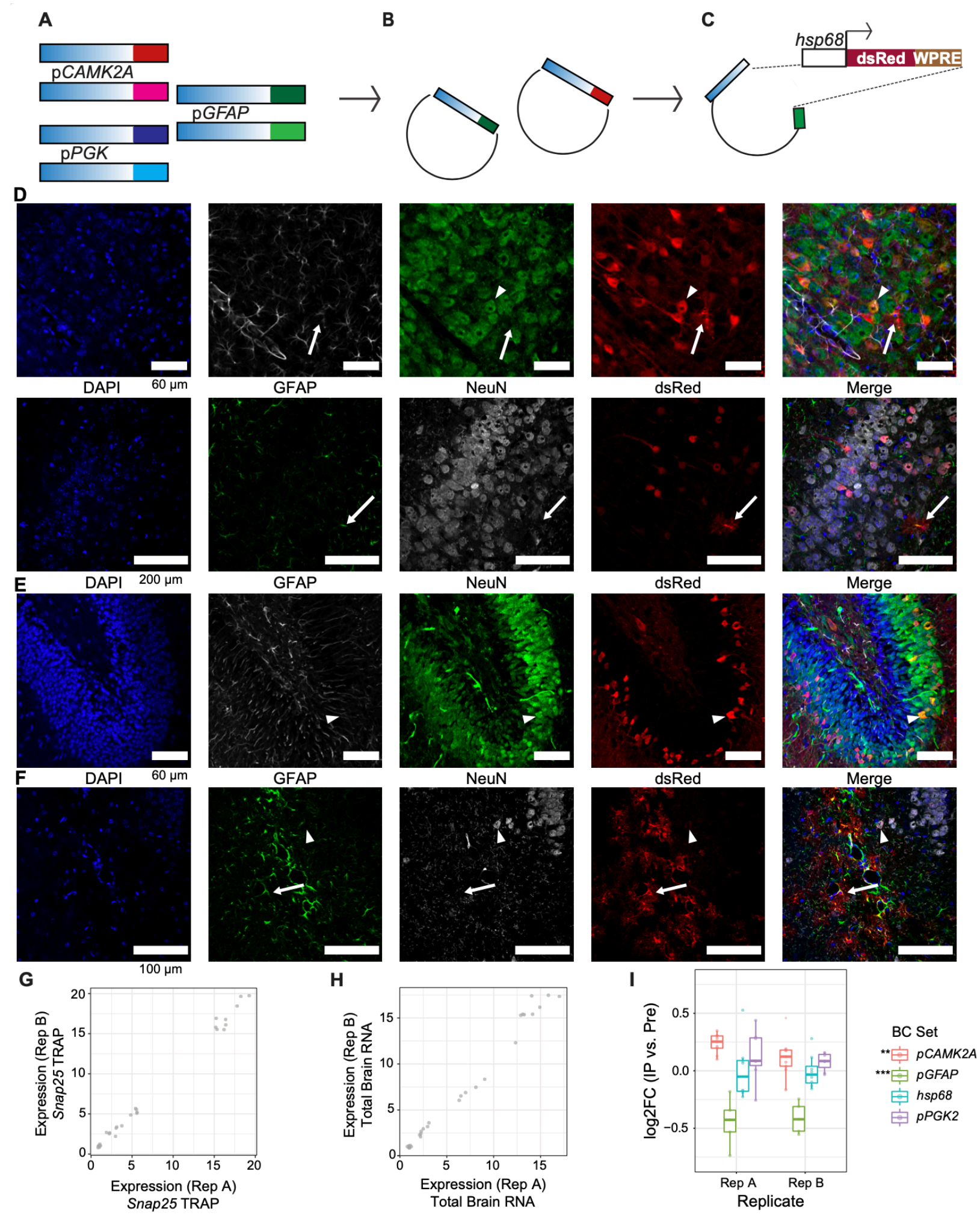

Figure 1. Proof-of-principle: cell type-specific MPRA in vivo. (A) Cell type-specific promoters, $p$ GFAP (astrocytic) and $p$ CAMK2A (neuronal) were barcoded by PCR. (B) Amplicons were cloned into an AAV plasmid. C) Further restriction cloning added a reporter cassette containing a minimal hsp68 promoter, dsRed, and an RNA-stabilizing 3' UTR hepatitis E "woodchuck" (WPRE) element. Barcoded pools with each promoter were packaged into AAV9 separately. (D-F) IF of P27 mouse brain after P2 injection with a single AAV9 barcode 
pool. (D) hsp68 promoter alone preferentially drove dsRed expression in neurons, while (E) $p$ CAMK2A drove reporter expression solely in neurons, and (F) $p$ GFAP drove predominantly astrocytic dsRed expression. (G) Replicability of barcode expression for the SNAP25-TRAP RNA fraction (Pearson's $r=0.9975)$ and $(\mathbf{H})$ total brain tissue (input) $(r=0.9927)$. (I) TRAP expression, compared to total brain expression, was higher for $p C A M K 2 A$ and lower for $p G F A P$, as expected. ${ }^{* *} p \leq 5 \times 10^{-4},{ }^{* * *} p \leq 5 \times 10^{-8}$

\section{Identification of rSNPs and their sex-allele interactions in total hippocampus and excitatory neurons}

Given the association of MDD with sex, hippocampal pathology, and neuronal genetics, we sought to identify regulatory SNPs among variants selected from broad linkage disequilibrium (LD) regions associated with MDD in total hippocampus. To further investigate the roles of SNPs and sex in hippocampal excitatory neurons in particular, we performed these experiments in a cross of Slc17a7 (or, Vglut1)-Cre mice (38) to a Cre recombinase-dependent TRAP mouse line (37).

The analyzed MPRA library covered 40 GWAS loci spanning $~ 1,000$ SNPs in LD $\mathrm{R}^{2}>0.1$ with MDD-associated tag variants. SNPs were prioritized by their overlap with human brain and neural cell type eQTLs, histone marks, enhancer RNA overlap, and chromatin contacts (see Data Availability). Of these SNPs, 926 were from 29 MDD GWAS loci (6, 7, 32, 39-43), 19 were from 2 loci identified by meta-analysis of MDD and autism spectrum disorders (44), and 21 were from 4 loci for MDD-correlated traits (mood instability, anxiety, and neuroticism) (4548). 126bp human genomic sequences centered on the SNP were generated for each allele and paired to 10 unique $10 \mathrm{bp}$ barcodes per allelic sequence for internal replication (Fig. S1). These were inserted into an AAV plasmid, then cloned to contain an hsp68 minimal promoter (49) reporter RNAs (50), and packaged into AAV9. 
We delivered the AAV9 library bilaterally into the hippocampus of Vglut1-TRAP mice ages P60-P80 ( $\mathrm{n}=6$ per sex), followed by hippocampal dissection and TRAP (Fig. 2A) to identify rSNPs and their shared regulatory features (Fig. 2B). IF of hippocampi from additional mice confirmed robust hippocampal expression of the dsRed reporter 28 days after injection (Fig. 2C). as expected (Fig. 2D), then conducted MPRA sequencing (Table S1) and analysis of both input RNA (hippocampus) and TRAP RNA $\left(\right.$ Vglut1 $^{+}$) for each sample.

A
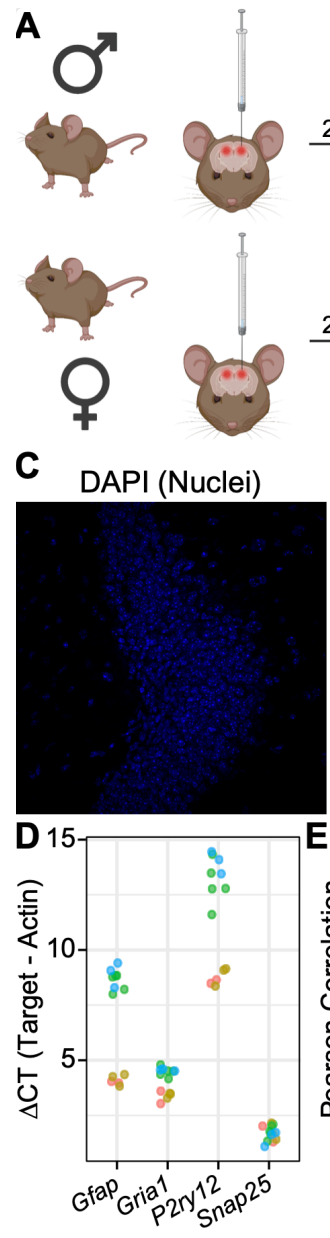

Gene
28 days
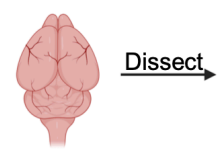

$\stackrel{28 \text { days }}{\longrightarrow}$

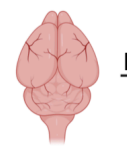

$\stackrel{\text { Dissect }}{\longrightarrow}$
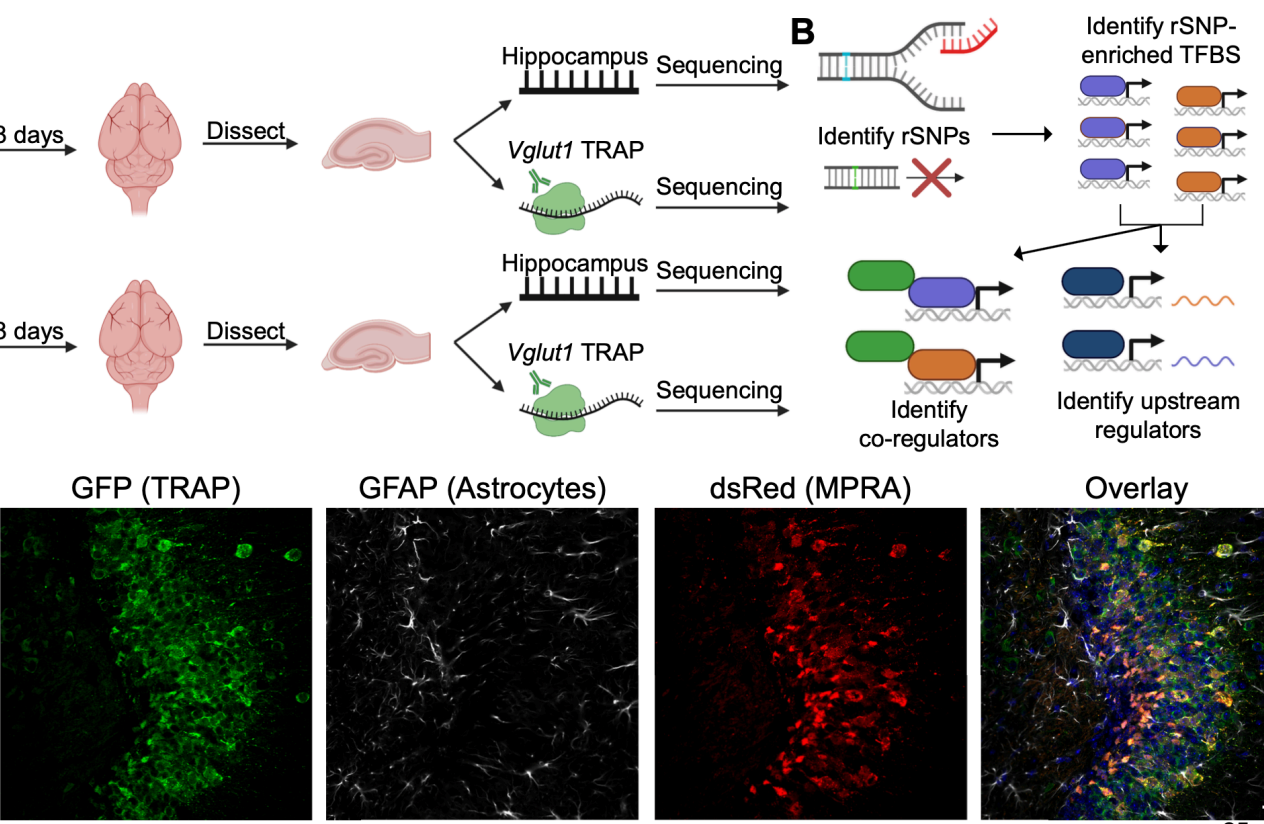

GFAP (Astrocytes)

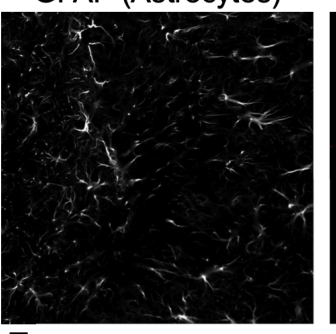

dsRed (MPRA)
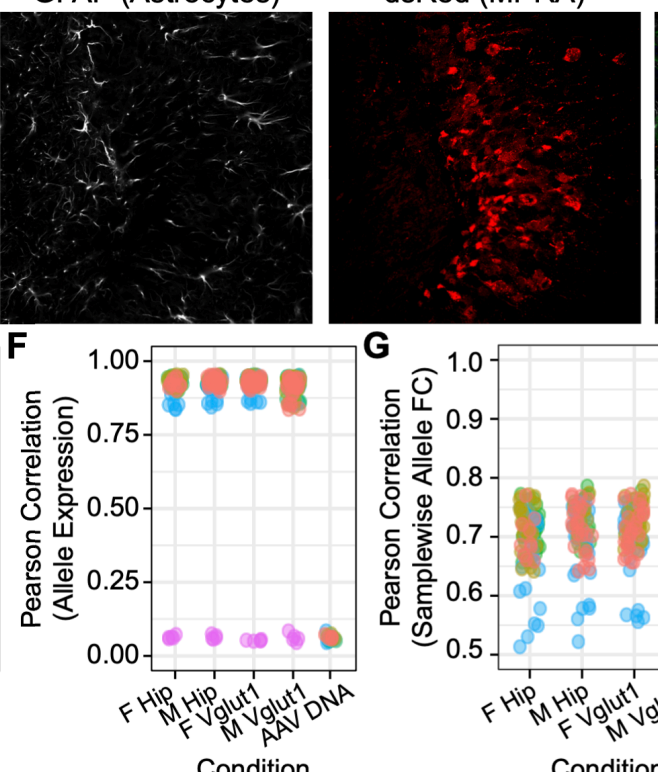

Condition
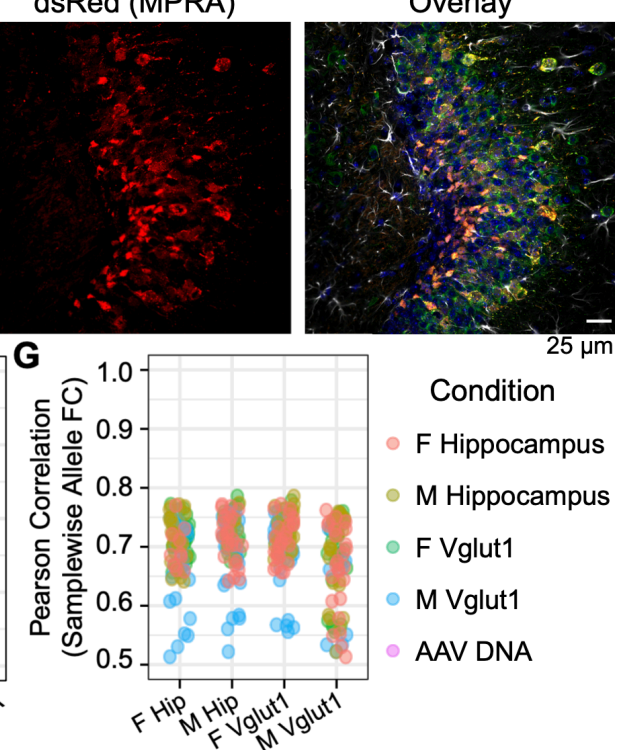

Condition

F Hippocampus

M Hippocampus

F Vglut1

M Vglut1

AAV DNA

Figure 2. Experimental design, analysis plan, and quality control: adult mouse

hippocampus and its excitatory neurons. (A) Adult male and female C57BL/6J mice received bilateral stereotactic injections into the hippocampus delivering the AAV9-packaged MPRA.

TRAP yielded two RNA fractions per sample: "input" (total hippocampal) and TRAP (Vglut1 ${ }^{+}$).

(B) Analyses identified regulatory SNPs (rSNPs), transcription factor (TF) binding sites (TFBSes) enriched at rSNPs, shared protein interactors among these TFs, and shared regulators 
of these TFs' expression. (C) IF of Vglut1-TRAP mouse hippocampus 28 days after MPRAAAV9 delivery, illustrating strong TRAP (GFP) co-expression with dsRed reporter, confirming RNA from the latter is present in the cell type of interest. (D) qPCR confirmed depletion of glial genes (Gfap, P2ry12) and modest enrichment of excitatory neuron marker Grial in Vglut1 ${ }^{+}$ RNA. (E) Barcode count correlations between replicates. Each point represents the crosscorrelation between one sample of the type on the X-axis and one of the color-coded type. (F) Correlation of mean barcode expression between replicates. (G) Correlation of samplewise allelic differences in expression. PCC: Pearson correlation coefficient (or Pearson's $r$ ).

After quality control, $n=5$ male and $n=5$ female hippocampal samples (both the input and TRAP RNAs) were retained for MPRA analysis covering 1,000 SNPs (see Online Methods). These showed replicability at the level of barcode counts (pairwise Pearson's $r$ 0.7-0.89) (Fig. 2E), RE-level expression ( $r$ 0.85-0.96) (Fig. 2F), and allelic fold changes within each condition (r 0.90-0.94) (Fig. 2G), confirming we were able to reliably measure SNP-mediated regulatory effects and differences from a defined cell type in vivo.

\section{rSNPs in the adult hippocampus and hippocampal Vglut $1^{+}$neurons}

We first assessed $\sim 1,000$ SNPs for allelic effects in each individual sex and RNA fraction, using linear mixed models (LMMs) fitting barcode expression as a function of allele with random barcode effects (see Online Methods and Fig. S2-S4). We calculated empirical $p$ ( $\left.p_{\text {emp }}\right)$ values using 50,000 simulated 'allelic' comparisons between subsets of random barcodes coupled to the minimal promoter alone $(26,51)$ to account for technical and barcode-mediated noise. Significance was called at FDR-corrected $p_{\mathrm{emp}}<0.2$, a stringency comparable to a recent study of sex-interacting eQTLs (21). Supplemental Data S1 provides allelic beta $(\log 2 \mathrm{FC})$ values and significance status for variants at 10 different significance thresholds.

In total hippocampus, we identified 36 (male) and 31 (female) rSNPs, 34 and 31 of which were from MDD loci, respectively. While male and female total hippocampi had similar numbers of rSNPs, we observed a striking sex difference in the number of rSNPs in $\mathrm{Vglut}^{+}$cells specifically_only 7 (male) compared to 58 (female), indicating that within excitatory neurons, a 
higher proportion of MDD SNPs have discernible allelic effects in females. . Moreover, all 7 male rSNPs were also functional in females. Notable rSNPs from $\geq 1$ condition included rs2563323 and rs250427, putative brain and hippocampal (52) eQTLs for SRA1, a noncoding RNA which activates nuclear receptors even in the absence of their ligand (53). Also notable were rs301806 — an MDD GWAS index SNP (40)—and rs301807 (Fig. 3A-B), both of which likely regulate the nearby gene $R E R E(15,54)$.

\section{Sex-interacting rSNPs in hippocampus}

Given the role of sex in MDD risk and the observed differences in rSNP activity in the adult hippocampus, we sought to investigate whether sex interacts with MDD risk genotypes. To ensure there were not confounding sex differences in minimal promoter activity, we compared minimal promoter-only barcode expression between sexes for the two tissue fractions, finding no sex difference in activity ( $t$-test of barcode expression, $\mathrm{p}>0.5$ in both comparisons; Fig. S5). 

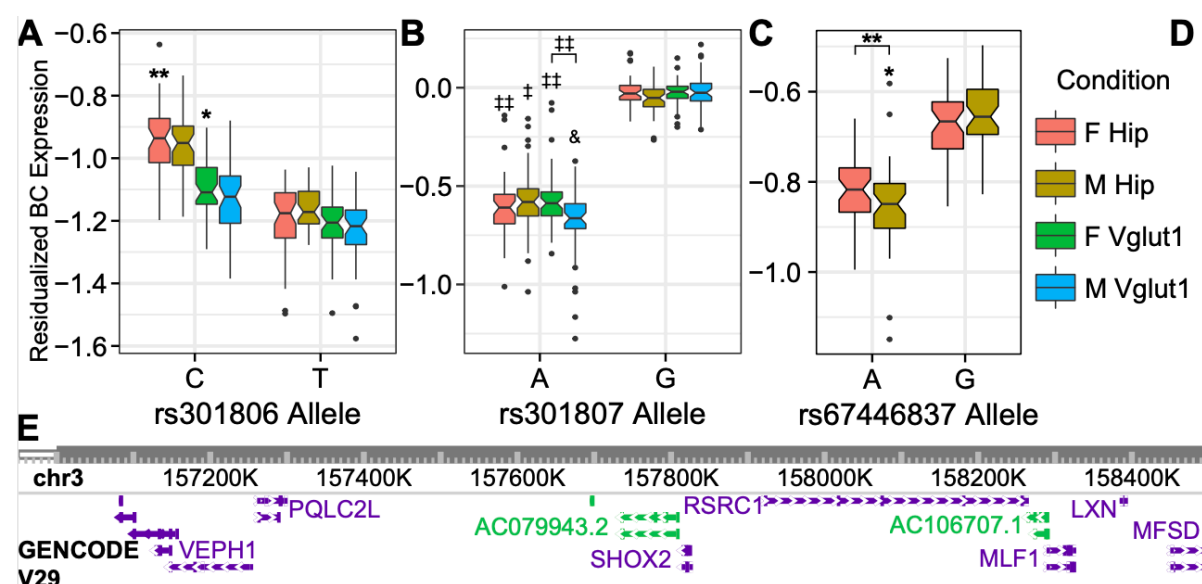

rs301807 Allele

rs67446837 Allele
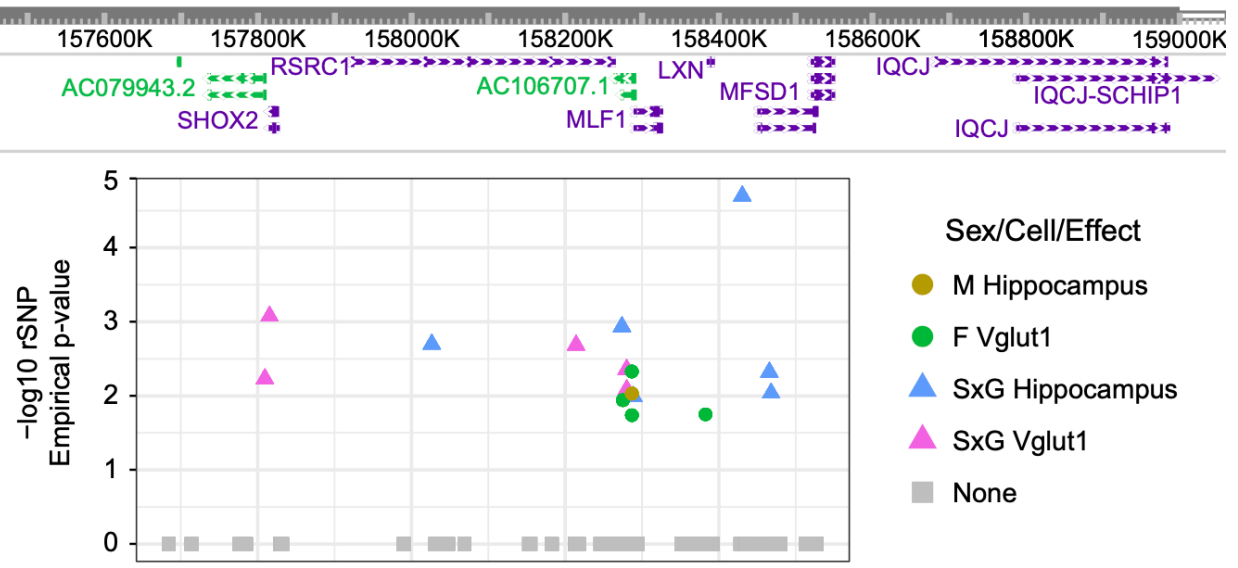

Sex/Cell/Effect

M Hippocampus

F Vglut1

SxG Hippocampus

S SxG Vglut1

None

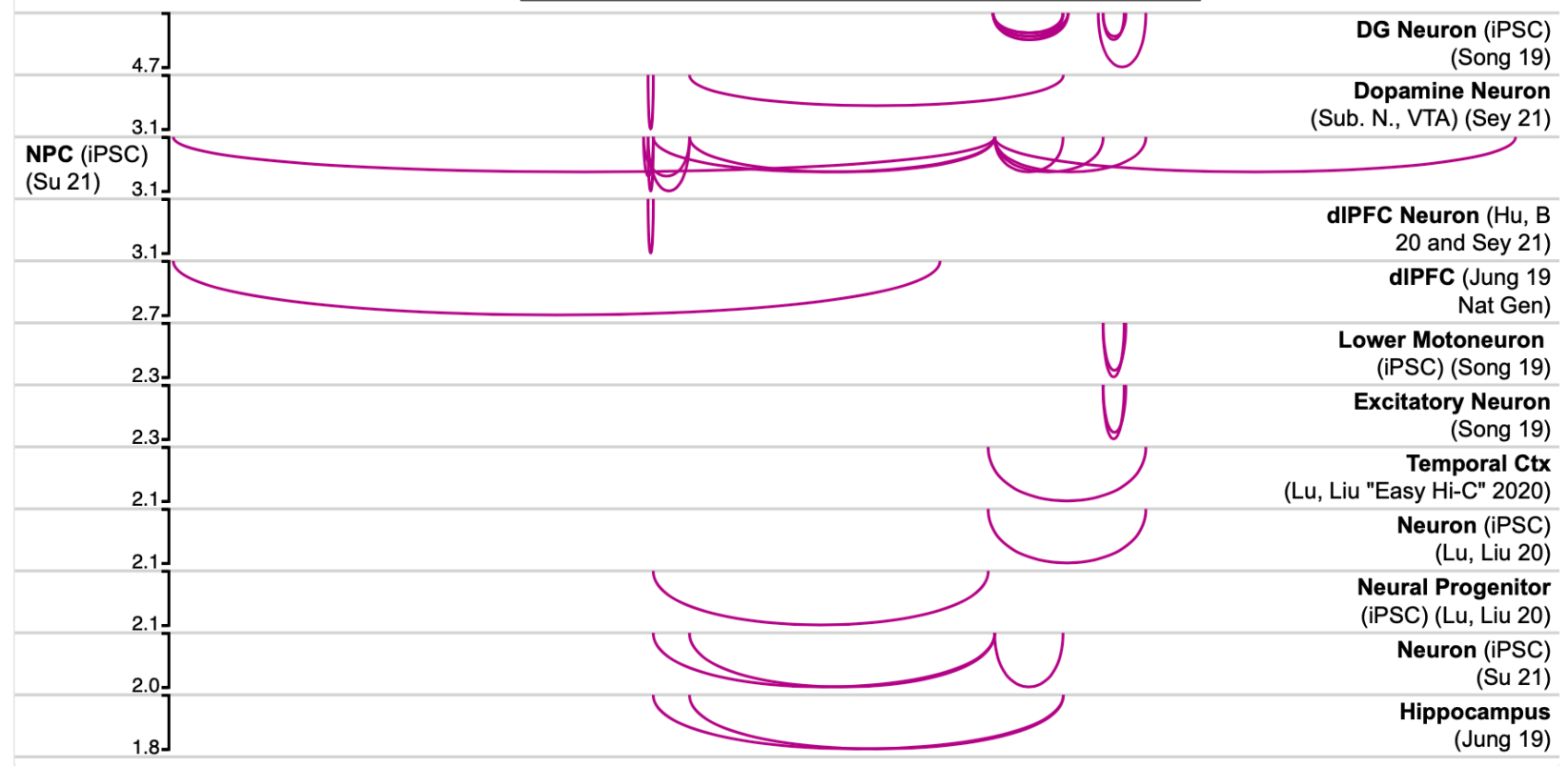

Figure 3. Adult hippocampus rSNPs and complex context-dependent, polygenic architecture of the RSRC1 locus. Boxplots show single-barcode (BC) expression levels adjusted for random effects across analyzed replicates. Center bars: median; boxes: $25-75 \%$ quantile; whiskers: observations spanning box edges to $\pm 1.5 *$ interquantile range (IQR); single points: observed values outside whisker range. Notched regions span $\pm 1.58 * \mathrm{IQR} / \mathrm{sqrt}$ (n measurements), approximating the $95 \%$ confidence interval for comparing median $\mathrm{BC}$ expression (55). rSNPs corresponding to RERE locus (32) tag variants (A) rs301806 and (B) rs301807 are shown. (C, D) Sex-interacting SNPs from the $R S R C 1$ locus (39) included (C) rs67446837 and (D) rs1048243. (E) rSNPs identified in the $R S R C 1$ locus and their regulatory target genes in human tissues ascertained by Hi-C. A plot of rSNP effects, colored by most 
significant condition, is embedded with its X-axis in human genomic (hg19) coordinates; chromatin contacts between the SNPs and distal gene promoters are illustrated below (56-61). Curve heights correspond to $-\log 10 p_{\text {emp }}$ for the plotted rSNP. iPSC: Induced pluripotent stem cell; DG: dentate gyrus; Ctx: cortex. * $p_{\text {emp }}$-derived FDR $<0.25 ; * *:<0.2 ; \uparrow<0.15 ; \hbar+<0.1 ; \&$ $<0.05$.

We therefore performed combined-sex LMM analysis of the $\mathrm{Vglut}^{+}$and hippocampus results, identifying 41 sex-allele interaction rSNPs in each. Notably, while only $1 \mathrm{SxG}$ rSNP was shared between total hippocampus and $\mathrm{Vglut}^{+}$, sex-interacting SNPs originated from the same GWAS loci across both analyses. The tag locus rs1193510 (39), for example, contained 11 sexinteracting rSNPs, including several unique to hippocampus (Fig. 3C) or Vglut1 ${ }^{+}$(Fig. 3D). This region is rich in human neural chromatin contacts (56-61), implicating several target genes of the identified rSNPs. Interestingly, SxG effects in hippocampus and $\mathrm{Vglut}^{+}$segregated into distinct portions of this LD region (Fig. 3E). We additionally examined three SNPs in our assay that were recently reported significant in sex-genotype interaction GWASes of over 500 traits (62). One of these reported variants, rs2400075, was found to have several significant sexinteracting associations to body traits; this variant is located near LIN28B - which shows sexdifferential expression in mouse norepinephrine neurons (63)-and was a near-significant SxG rSNP in $\operatorname{Vglut}^{+}(0.20<\mathrm{FDR}<0.25)$.

Transcriptional-regulatory systems shared across hippocampal rSNPs

We next asked whether there were any shared transcriptional-regulatory mechanisms underlying MDD rSNP effects in the hippocampus. We tested whether rSNPs perturbed specific transcription factor (TF) binding motifs more frequently than expected by chance (defined by their rates in rSNPs vs. non-effect SNPs in the assay) (26). We assessed motif disruptions using motifbreakR (64) and RSAT var-tools (65) (see Online Methods) defining rSNPs at a nominal LMM $p_{\text {emp }}$ of 0.05 . This resulted in sets of 80-110 MPRA-identified rSNPs per condition ( $p_{\text {emp }}$ 
FDR levels of 0.22-0.28; Data S2A), ensuring adequate depth for enrichment analysis — akin to other methods which loosen significance thresholds to analyze higher-order relationships of granular molecular measures, e.g., polygenic risk scoring or gene ontology. To refine these results, we filtered the enriched TFs $($ FDR $<0.05)$ to those with altered putative binding sites $\geq 4$ rSNPs and expressed in Genotype-Tissue Expression atlas (v8) hippocampus in the corresponding sex.

Altogether, we identified 34 enriched TFs in male total hippocampus rSNPs and 19 in female. The hippocampal TFs identified were largely distinctive between sexes; for example, KLF family TFs were unique to male hippocampal rSNPs, while nuclear receptor (NR) TFs were mostly unique to female rSNPs (Fig. 4A). Among Vglut $1^{+}$rSNPs, we identified 8 TFs in female and 16 in male, many of which were shared (e.g., DLX1, POU3F1/2/3). POU3F2 has been previously shown to be a highly centralized, cross-disorder hub gene in postmortem brain coexpression analysis by PsychENCODE (66).

To understand integrative biological functions of these TF sets, we utilized the tool Enrichr (67) for each TF set, including both tissues per sex, to identify putative upstream regulators, co-interacting TFs (protein-protein interactions (PPIs)), enriched disease gene sets, ontologies, and brain regions expressing the TFs (Data S2B-C). The most striking enrichments ( $>25 \%$ of query TFs) for male glutamatergic and hippocampal TFs combined were for regulators of these TFs' expression, including CREB1 (14/48), BRCA1 (19/48), and ZBTB7A (12/48). Male hippocampal TFs were likewise enriched for several upstream regulators, including TCF3 (8/38), HDAC2 (8/38), and ZMIZ1 (9/38). ZMIZ1 has roles in coactivation of androgen receptor $(A R)(68)$ as well as SMAD3 (69), consistent with enrichment of these TFs in SMAD3 (6/38) and AR (7/38) PPIs. TFs from male glutamatergic neurons were enriched for four PPIs: SMAD3 and SMAD4 (both 5/16), consistent with MPRA signal from neuronal enrichment 
by TRAP, and more surprisingly, sex hormone receptors: estrogen receptor $\alpha(E S R 1 ; 4 / 16)$ and $A R(3 / 16)$.

Likewise, female glutamatergic TFs were enriched for PPIs with SMAD3 (3/8), along with $R X R A(3 / 8)$, replicating in vivo our recent in vitro findings of retinoid-interacting rSNPs in MDD-associated loci (26). Female total hippocampal TFs, on the other hand, were enriched for upstream regulation by several TFs, including ATF2 (9/19), BRCA1 (8/19), and TCF3 (5/19).

\section{Transcriptional-regulatory systems implicated in SxG interactions at MDD rSNPs in}

\section{hippocampus}

Using a similar approach to that above, we investigated TFs enriched at sex-allele interaction rSNPs $\left(p_{\mathrm{emp}}<0.05\right.$, corresponding to FDRs of $\left.0.34-0.37\right)$ relative to sex-agnostic rSNPs (combined-sexes LMM allele main effect $p_{\text {emp }}<0.05$ ), and separately enriched to nonfunctional SNPs, then combined the two enrichment outputs to form TF sets (see Online Methods) (Fig. 4A). We identified only 8 TFs enriched among total hippocampal SxG rSNPs, including ZNF410 and five TFs with a shared binding motif for $F O X(C 1 / J 2 / J 3 / O 4 / P 1)$. NR1H2), and another retinoid TF, RARA. 
bioRxiv preprint doi: https://doi.org/10.1101/2021.11.01.466849; this version posted November 4, 2021. The copyright holder for this preprint (which was not certified by peer review) is the author/funder, who has granted bioRxiv a license to display the preprint in perpetuity. It is made available under aCC-BY 4.0 International license.

A
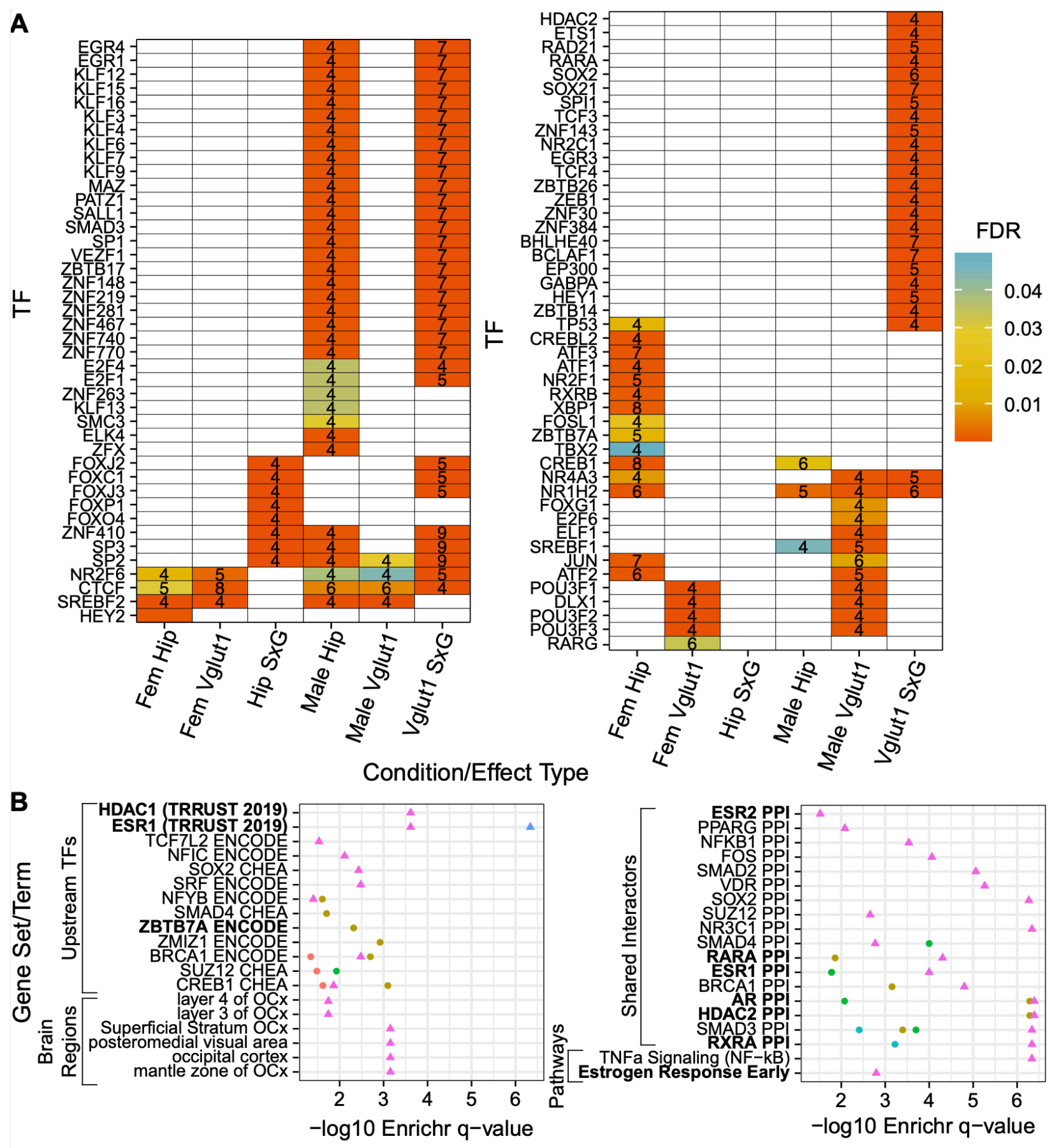

Condition

- F Hippocampus - M Hippocampus - F Vglut1 $\bullet$ M Vglut1 $\triangle$ SxG Vglut1 $\triangle$ SxG Vglut1 and Hip

Figure 4. Shared regulatory architecture of rSNPs by sex, cell type, and sex-interacting SNP type. (A) TFs with binding motif disruptions by $\geq 4$ nominally significant (empirical $p<$ 0.05 ) rSNPs or sex-interacting rSNPs, enriched relative to nonfunctional SNPs. Number of

rSNPs associated to a given binding site are shown. (B) Terms from Enrichr (67) analysis, identifying shared upstream regulators (TFs controlling expression of several of the TFs in panel A), brain regions enriched for expression of the rSNP-enriched TFs, protein interactors enriched among rSNP-enriched TFs, and MSigDB pathway term enrichment for rSNP-enriched TF sets. Bolded enrichments are discussed in the text. 
We ran both tissue fraction $\mathrm{SxG}$ TF sets through Enrichr, though nothing notable appeared for total hippocampus given the small size of the set. Top glutamatergic SxG TF enrichments included upstream regulation by BRCA1 (21/57) and CREB1 (15/57), as well as

PPIs with $A R(11 / 57)$, ESR1 (11/57), and HDAC2 (12/57) (Fig. 4B). Also enriched was an MsigDB functional gene set term, "estrogen response early" (5/57). These SxG regulators implicate sex hormones and histone acetylation in both establishing sex-divergent MDD risk from upstream, e.g. via ESR1 (5/57), and actuating it downstream via rSNP-enriched TFs and their protein interactors $(A R, E S R 1, H D A C 2, Z M I Z 1, Z B T B 7 A)$. Incidentally, both sex hormones (70) and histone (de-)acetylases (71) have been major areas highlighted in recent reviews of sex differences in MDD and mouse models thereof.

\section{Identification of rSNPs in developing whole mouse brain}

As sex differences in brain structure and transcriptional regulation are established in part by the effects of sex hormones, including the perinatal testosterone surge (33), we sought to investigate whether MDD risk variants were subject to sex-differential regulation during early development. To be able to assess the brain during this period, we delivered the AAV library intracerebroventricularly to embryonic day 15 (E15) mice, followed by whole brain collection at postnatal day 0 (P0) and P10 (see Online Methods). P0 — while not amenable to regionallytargeted viral assays - is in the midst of the testosterone surge, during which both acute activational effects and transcriptional-regulatory organizational effects occur; by contrast, P10 is a timepoint where sex hormones are effectively absent in normal development. 

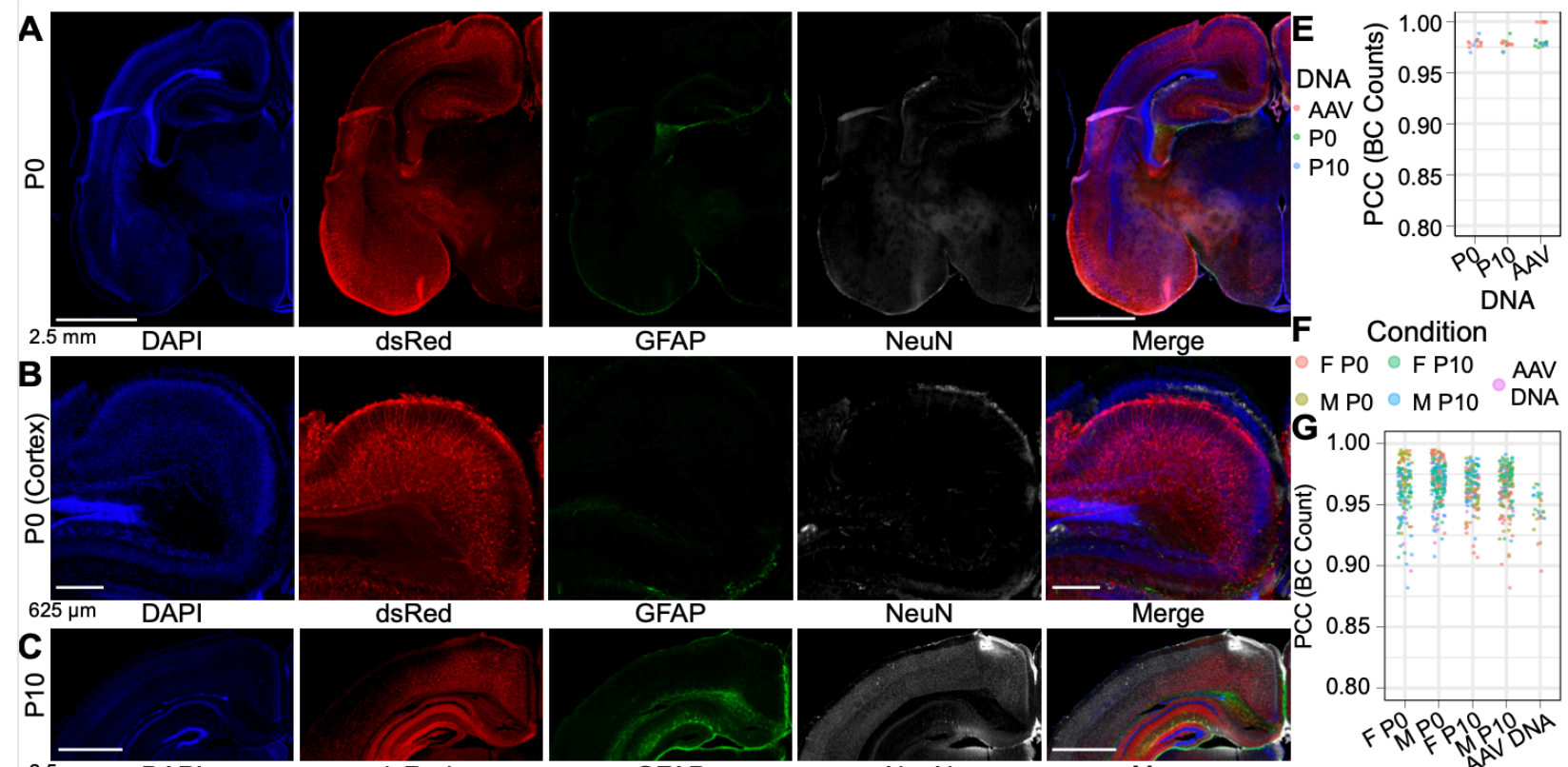

GFAP

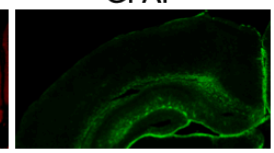

NeuN

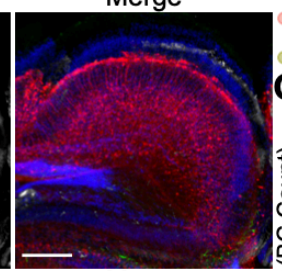

Condition

DNA

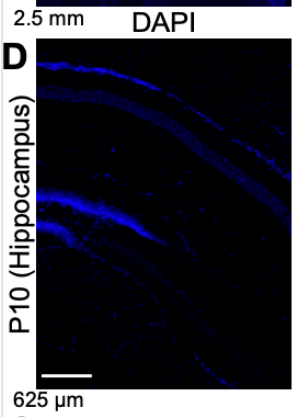

dsRed

GFAP
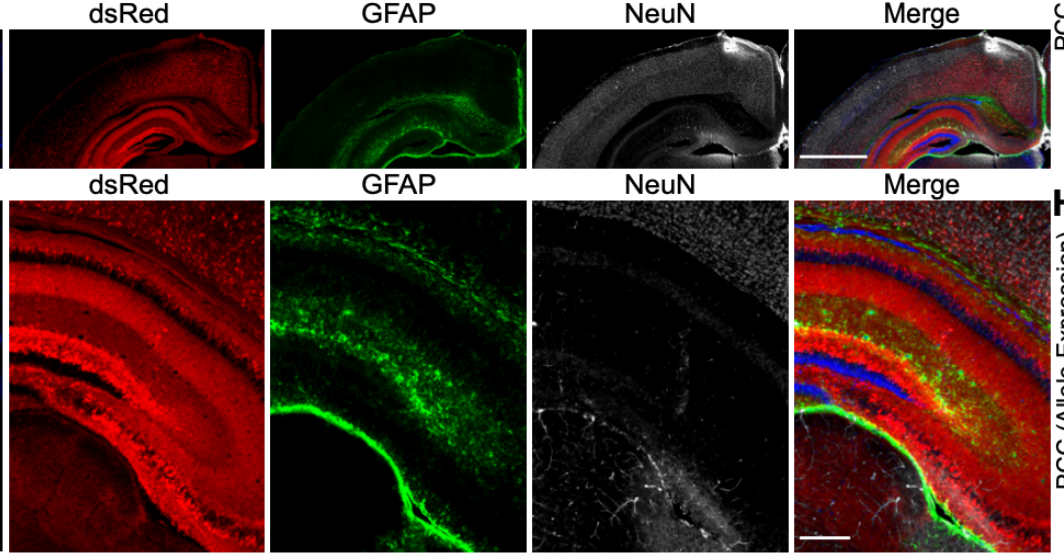

FP0 $\odot$ P10 AAV

I

$\mathbf{J}$
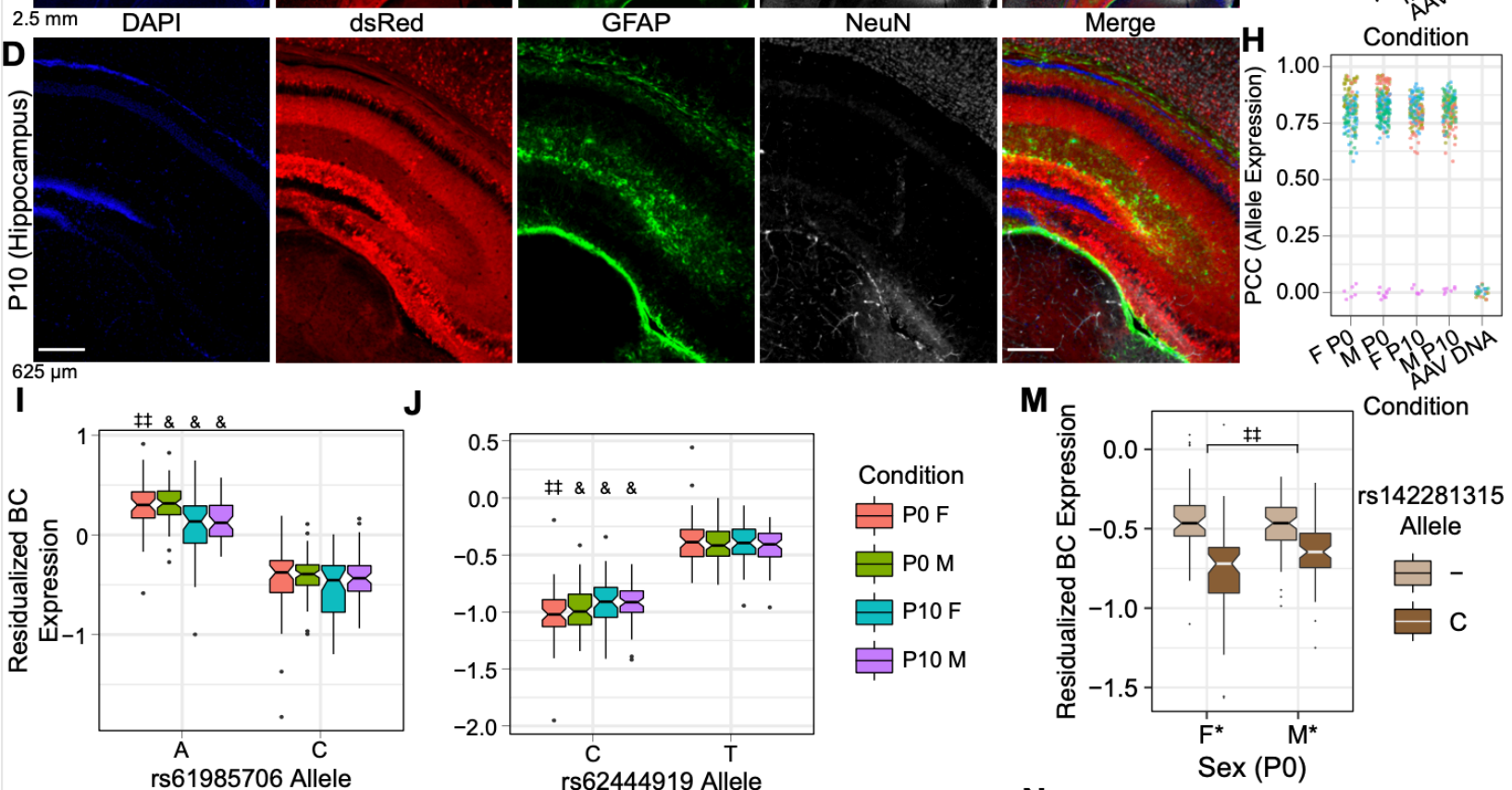

$\mathbf{K}$

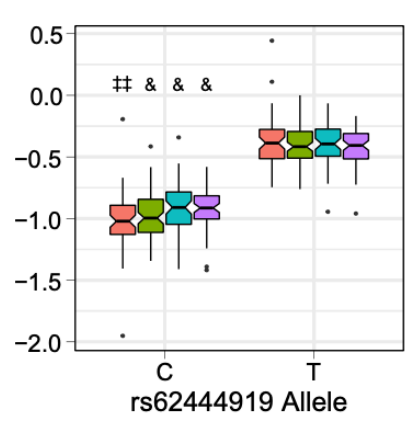

Condition

官POF

$\mathbf{M}_{\text {c }}$
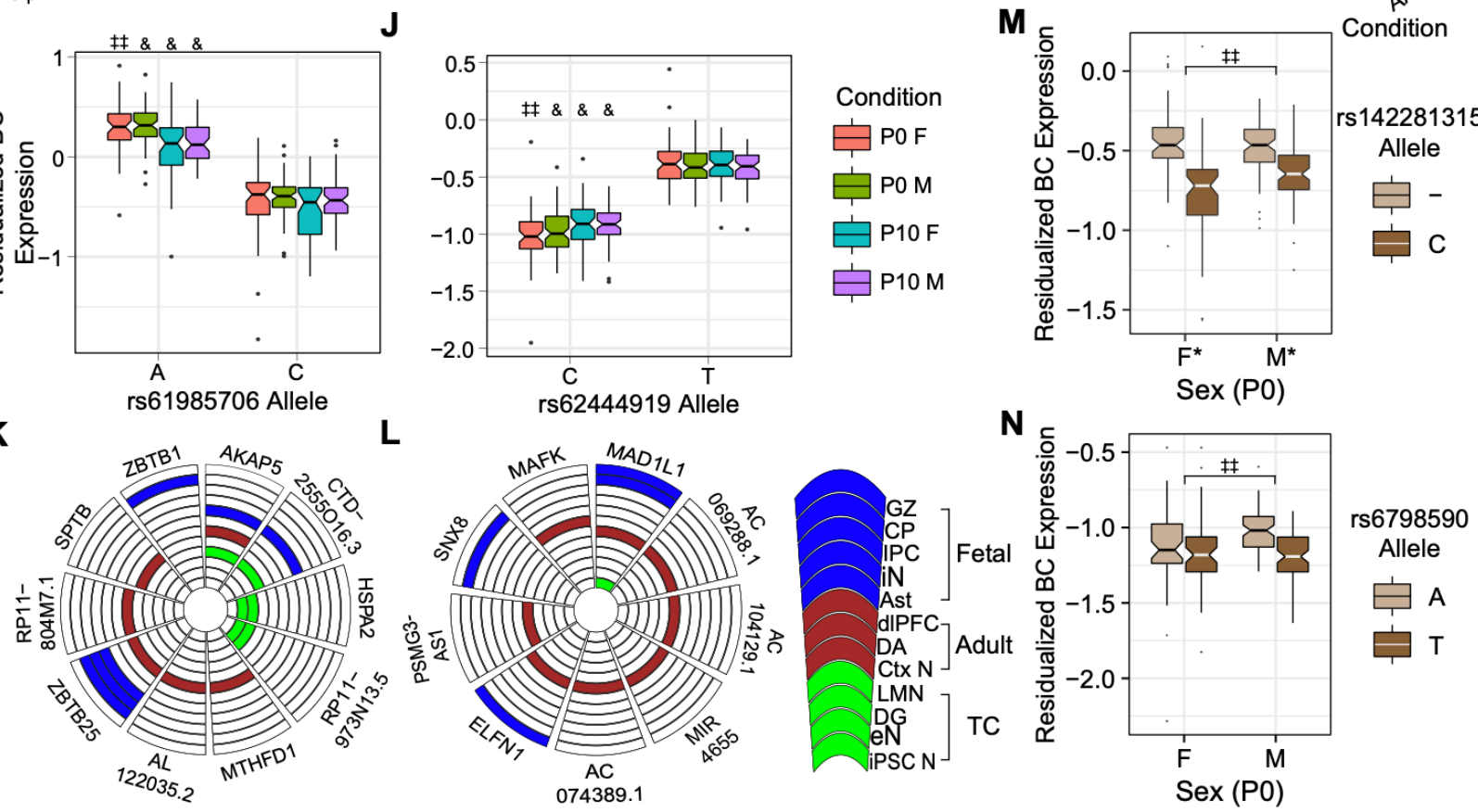

Figure 5. Validating the in utero MPRA delivery method, and identification of rSNPs and sex-interacting rSNPs in the developing brain. (A, B) IF of P0 brain after E15 MPRA-AAV delivery. (C, D) IF of P10 brain after MPRA-AAV delivery. (E) Comparability of barcode counts in recovered brain DNA and original AAV. (F) Color legend for panels G-H. (G) BC 
count correlation between samples. (H) Sequence expression correlation between samples. (I, J) rSNPs (I) rs61985706 and (J) rs62444919 (J) showed effects consistent across sexes and ages. $(\mathbf{K}, \mathbf{L})$ Putative target genes of the respective rSNPs from Hi-C in human fetal, adult, and cultured neural tissues. (M) Example P0 SxG SNP with comparatively small sex difference in allele effect size. (N) Example P0 SxG SNP with magnitude of sex difference in allelic effect comparable to smaller (female) allelic effect itself. GZ: germinal zone; CP: cortical plate (72); IPC: intermediate progenitor cell; iN: inhibitory neuron (15); Ast: astrocyte (58); dlPFC: dorsolateral prefrontal cortex; DA: dopamine neurons of substantia nigra and ventral tegmental area (56); Ctx N: cortical neuron (61); LMN: lower motor neuron; eN: excitatory neuron (58);

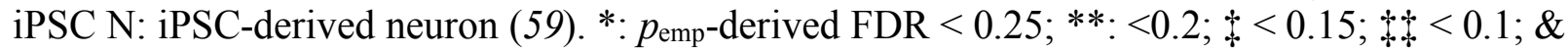
$<0.05$.

We first verified by IF that dsRed expression was detectable at P0 and P10 following in utero delivery. Clear, widespread reporter expression was apparent at both timepoints despite the relatively short incubation time (Fig. 5A-D; Fig. S6). IF at P10 demonstrated prominent expression of the reporter in the hippocampus (Fig. 5D) - a structure neither present at E15 nor well-developed at P0 — consistent with prior observations of AAV9 expression ultimately occurring in hippocampus when delivered to the perinatal brain (73). We subsequently collected the whole brain (except cerebellum) for RNA isolation and MPRA sequencing. Additionally, we isolated DNA from $n=4$ brain samples (one per age and sex) to profile the transduced library contents, verifying that the distribution of delivered MPRA barcodes was similar both between replicates ( $r$ 0.86-0.94) and to input virus ( $r$ 0.88-0.91) (Fig. E). Ultimately, we analyzed 15 samples for P0 (6 female, 9 male) and 13 for P10 (6 female, 7 male; see Supplemental Text). Replicates from each condition had well-correlated barcode counts (PCC 0.86-0.98) and RE expression values (PCC 0.58-0.96) (Fig. 5F-H).

Within single sexes at P0, we identified 5 rSNPs in females and 12 rSNPs in males, respectively ( $p_{\text {emp }}$ FDR $<0.2$ ), 4 of which were shared between conditions with consistent effect direction. By contrast, we identified 105 female and 72 male rSNPs at P10, with 42 rSNPs identified in both conditions with consistent direction of effect. 4 of these shared rSNPs were the same rSNPs shared between P0 sexes, with consistent effect direction in all four conditions (two 
of which are illustrated, Fig. 5I, J). Three of these four rSNPs also have rich chromatin contact evidence supporting gene regulatory roles in fetal, adult, and cultured human neural cell types (for the illustrated rSNPs, Fig. 5K and $\mathbf{5 L}$, respectively), consistent with their detection as rSNPs in whole brain tissue, highlighting in utero MPRA delivery as a robust method for detecting functional variation in the developing brain.

\section{Sex-allele interactions are widespread neonatally but absent during hormonal quiescence}

To identify SxG interactions occurring during neurodevelopment, we tested for SxG interactions as before, now within age groups. Again, the minimal promoter-only control was not sex-differentially expressed ( $t$-test of barcode expression, $p>0.1$ ) (Fig. S7). At $p_{\text {emp }}$ FDR $<0.2$, we identified 31 rSNPs with sex interactions in the P0 brain (e.g., Fig. 5M-N). By contrast, we identified no $\mathrm{SxG}$ interactions at $p_{\text {emp }} \mathrm{FDR}<0.25$ among the 930 analyzed SNPs at P10. We confirmed this result_-despite similar $n$ and inter-sample correlations to P0 — by repeating the SxG analysis with the least variable 5 samples per sex (removing two males and one female)

\section{(Data S3).}

\section{development}

We examined single-sex, single-age rSNP sets for enrichment of TF motif perturbations using motifbreakR and RSAT approaches as before, and again using nominally significant ( $p_{\text {emp }}$ $<0.05$ ) rSNPs as the set tested for enrichment. We did not filter enriched TFs for expression in analogous human tissue, as fetal whole-brain gene expression profiles are unavailable; we instead required a more stringent minimum of 5 rSNPs to be found at significantly enriched $($ FDR $<0.05)$ TF motifs. 
In P0 brain, we identified 20 TFs enriched at female rSNPs and 43 at male rSNPs, 9 of which were shared (Fig. 6A). Shared transcription factors included EGR1/4, TBX1/15, and IRF9. Male-specific transcription factors again included $Z B T B 7 A$ and $N R 4 A 3$ (Fig. 6A). Femalespecific TFs included a variety of zinc finger TFs, Krüpell-like factors ( $K L F \mathrm{~s})$, endothelialdevelopmental regulator $S O X 17$, and the neurodevelopmental TF SMAD3 (Fig. 6A).

Despite the absence of sex interactions in the P10 brain, we also found largely distinct sets of TFs in each sex at this age (only 4 shared) (Fig. 6A). Among the 42 P10 male TFs, 38 were male-specific, including $R A R G$ - again supporting our in vitro findings of retinoidinteractivity (26) - and several $K L F$ members. (In contrast, $K L F$ s were instead only enriched at $\mathrm{P} 0$ in rSNPs from females). The 15 female P10 TFs were predominantly core transcriptional machinery, including $Y Y 1 / 2$, GTF3C2, TAF1, and in both sexes, CTCF.

We then looked at these TF sets as before to identify convergent regulators and functions among them (Fig. 6B; Data S2D-E). Of the few enriched annotations for male P0 TFs, we notably found that 4 corresponded to genes downregulated by Rara knockout, and 6 were putative regulatory targets of $P B X 3$, which shows widespread subcortical and midbrain expression in E18.5 and P4 mouse brain (74). Female P0 TFs were enriched in Allen Atlas expression signatures for cortical layers 1, 3, and 5, and, as found in hippocampus, in PPI targets of HDAC2 and ESR1. P10 male TFs showed the greatest extent of overlap (12/42) with generegulatory targets of $Z B T B 7 A$ and were enriched for PPI targets of $H D A C 2, R X R A$ and $R A R A$. The only enrichment found for P10 female TFs was via a modest (3/15) set of FOXA1 regulatory targets.

Transcriptional-regulatory systems implicated in sex-differential rSNPs postnatally 
Given the absence of FDR-corrected sex-genotype interactions at P10, we only analyzed P0 interaction rSNPs for TF motif perturbation enrichment. TFs enriched at interaction SNPs were comprised largely of $E G R, K L F$, and $S P$ family members, as well as $P A X 5$ and neurodevelopmental factor SMAD3 (Fig. 6A). Annotation of SxG TFs revealed a broader extent of hormonal roles in functional variation than observed in either sex alone at P0: we found $\mathrm{SxG}$ TFs were again enriched for PPI targets of ESR1 (as had been P0 female TFs), but additionally enriched in PPI targets of $A R$ and ESR2; the latter was otherwise absent from gene set analyses of TFs (Fig. 6B, Data S2D-E).

\section{Landscape of functional variation differs broadly across age, sex, and brain region/cell type} Sex-genotype interactions at MDD loci are overrepresented in hippocampus and its Vglut $1^{+}$ neurons

Finally, we wanted to test the hypothesis that the number of $\mathrm{SxG}$ interactions from the assayed SNPs exceeded what was expected by chance. We randomly scrambled sex labels and repeated our analyses to define a distribution for the null expectation regarding number of $\mathrm{SxG}$ rSNPs at a $p_{\text {emp }}$ FDR of 0.2. While our P0 SxG findings did not exceed chance expectations (Fig. 6C), our P10 results were consistent with a true absence of sex interactions (Fig. 6D). Most strikingly, the number of adult total hippocampal (Fig. 6E) and Vglut1 ${ }^{+}$(Fig. 6F) SxG interactions we identified were both significantly greater than would be anticipated. 
bioRxiv preprint doi: https://doi.org/10.1101/2021.11.01.466849; this version posted November 4, 2021. The copyright holder for this preprint (which was not certified by peer review) is the author/funder, who has granted bioRxiv a license to display the preprint in perpetuity. It is made available under aCC-BY 4.0 International license.

A

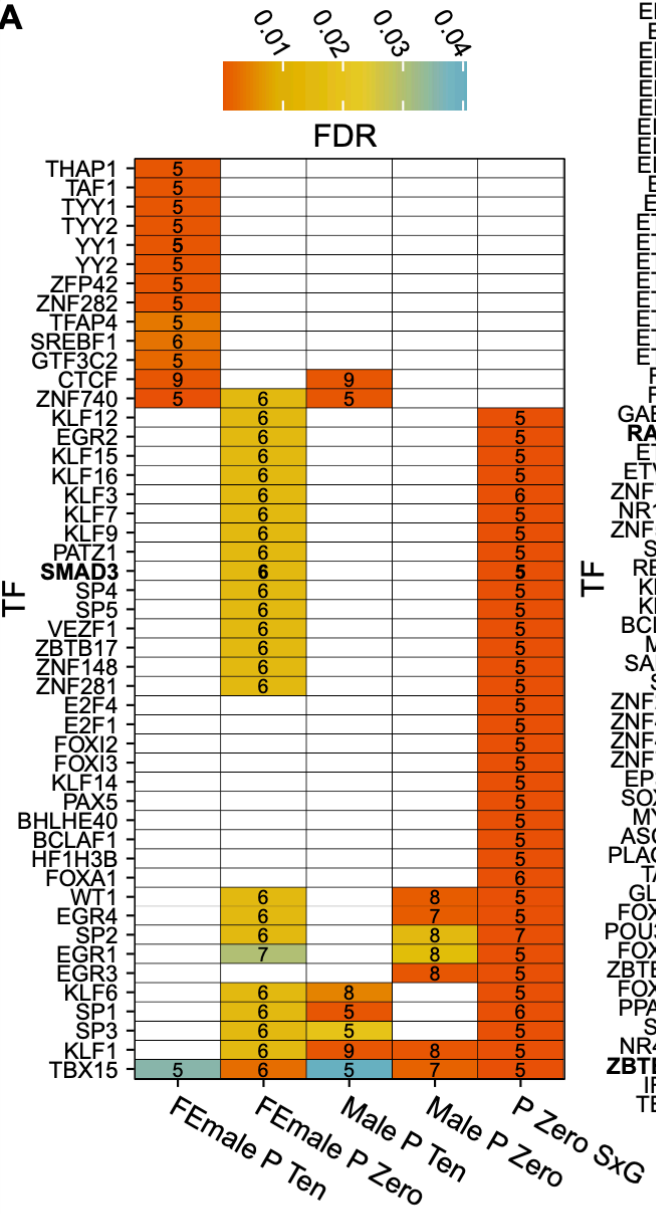

Condition/Effect Type

B

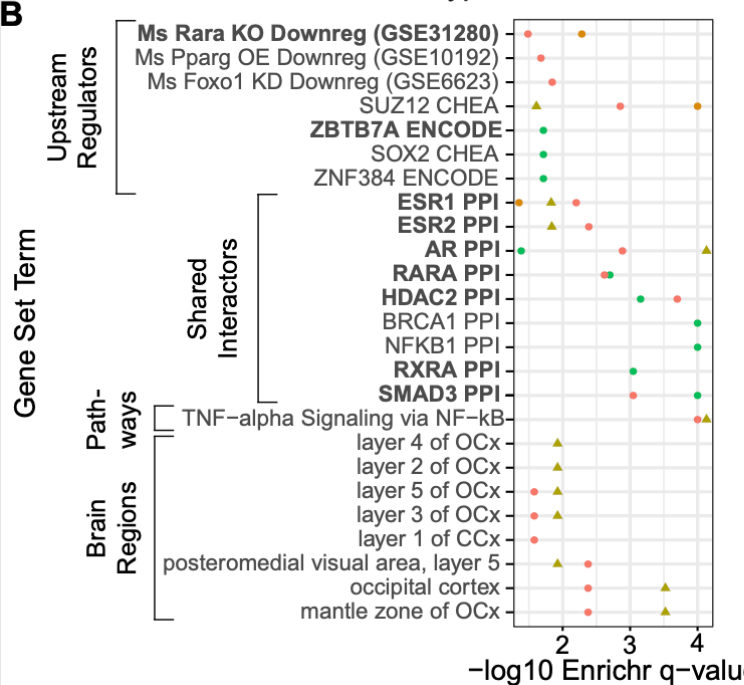

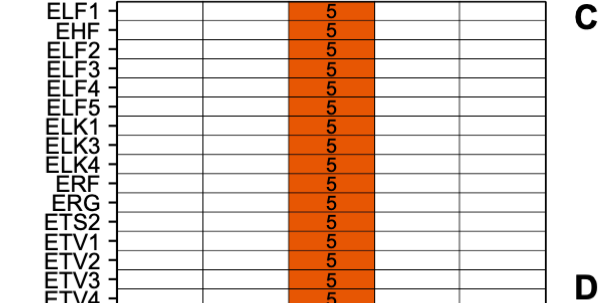

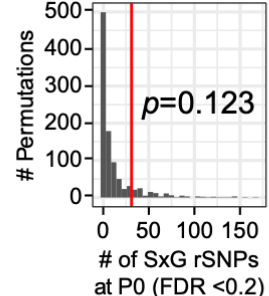

D

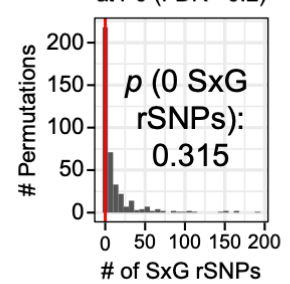

$\mathbf{E}$

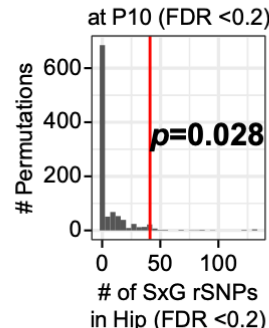

$\mathbf{F}$

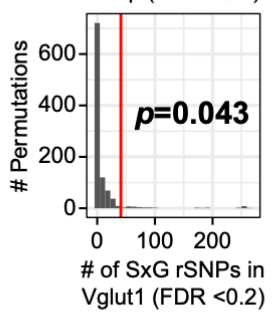

Condition/Effect Type

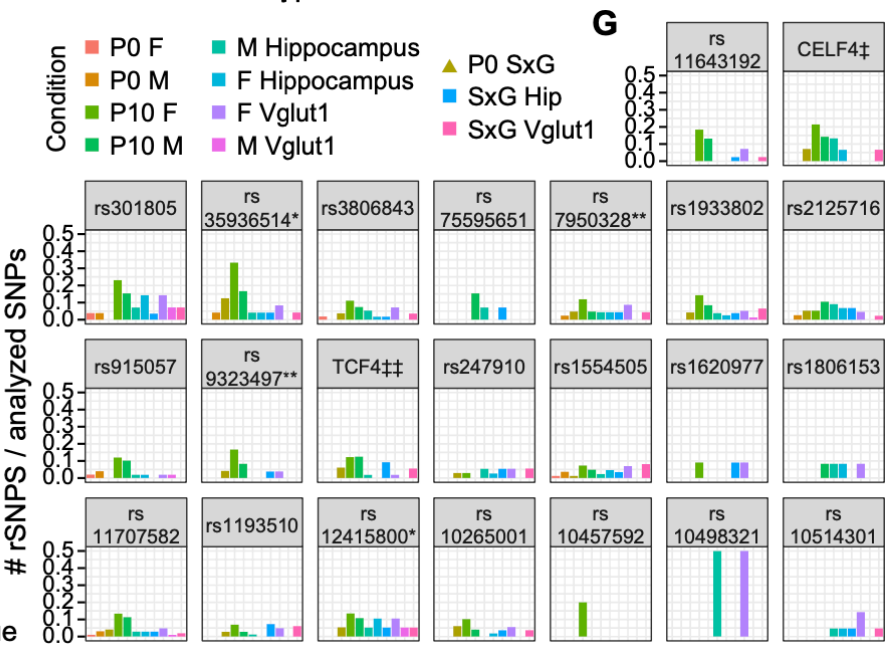

Figure 6. Regulatory architecture of rSNPs at P0 and P10, permutation analysis evaluating the number of detected SxG rSNPs, and the context-dependent landscape of MDD loci. (A) TFs with binding motif disruptions by $\geq 5$ nominally significant $\left(p_{\mathrm{emp}}<0.05\right) \mathrm{rSNPs}$ or SxG

rSNPs, enriched relative to nonfunctional SNPs. (B) Enrichr analysis findings for rSNP-enriched TFs in P0 and P10. Color key is shared with panel G. (C-F) Distribution of significant (FDR < 0.2 ) SxG rSNPs in 1,000 permutation analyses per condition (400 for P10); red lines: number of SxG rSNPs identified experimentally; overlaid $p$-values indicate the probability of observing as 
many SxG rSNPs by chance. (G) Each MDD locus, labeled by tag SNP, with bars representing the percentage of analyzed variants that were rSNPs or SxG rSNPs for each condition at $p_{\text {emp- }}$ derived FDR $<0.2$. Color key shared with panel B. *: locus from all-female MDD GWAS (42); **: near-genome-wide significant locus in males with MDD developing after age $50(41)$; + : collapsed results from two loci near CELF4 with tags less than $150 \mathrm{~kb}$ apart; +4 : collapsed results from LD partners of five tag SNPs, comprising two GWAS significant tags and several weaker association peaks covering a span of $\sim 5 \mathrm{Mb}$ around the gene TCF4 (6).

\section{Risk loci are characterized by multiple functional variants across age and cell type}

Overall, we found that it was the norm for loci to contain multiple functional, contextdependent SNPs, in contrast to the concept of a singular "causal variant" driving a given GWAS association. Altogether, our analyses identified 280 rSNPs from 31 LD regions (28 depressionassociated), with up to 13 rSNPs in a single locus found in a single condition (P10 female, tag SNP rs11707582 (6)) (Fig. 6G). In terms of age and cell type, we identified dozens of rSNPs with allele or SxG effects specific to one timepoint or tissue region: 26 P0-specific, 101 P10specific, 34 total hippocampus-specific, and 55 specific to $\operatorname{Vglut}^{+}$cells of the hippocampus. Indeed, only $64(\sim 23 \%)$ of rSNPs are functional in more than one developmental or cell type context. Similarly, 92 rSNPs were only identified as functional in female conditions and 37 only in male (excluding SxG interactions) — or, excluding P10, 36 in female and 16 in male-while another 86 were only subject to SxG interactions. In other words, only $23 \%$ of rSNPs were sexinvariant in their in vivo activity.

\section{Discussion and Conclusion}

We have directly measured sex-genotype interactions across MDD in the adult hippocampus and sexually differentiating brain, thus demonstrating the existence of a genetic component of sex differences in MDD and the regulatory architecture underlying these differences across space, time, and genome. We have uncovered functional differences between sexes at particular MDD-associated SNPs in the hippocampus, its excitatory neurons, and the 
brain during its sexual differentiation, expanding on observed genetic and clinical sex differences in MDD from general heritability to direct identification of sex-interacting variants.

Our data are supported by a wide variety of orthogonal datasets, including reporter assays and human brain epigenomic datasets beyond those used for variant prioritization. MDDassociated SNP rs1467013 was previously demonstrated to be functional in a classical luciferase reporter assay in three different cell lines (75). A prior in vitro MPRA identified rs301807, but not rs301806, as an rSNP (26), while both were identified as functional here. This highlights the importance of in vivo context for obtaining relevant insights about functional variation within GWAS loci-in this case, revealing two rSNPs in close $(\sim 2 \mathrm{~kb})$ proximity that likely influence expression of the same target $(R E R E)$.

Human datasets further support the translatability of our mouse approach in identifying regulatory SNPs and sex interactions. Four rSNPs identified here, rs7244124 (Vglut1 ${ }^{+}$SxG), rs76931017 (P10 female), rs827187 (P10 female), and rs4482931 (male hippocampus) were recently identified as chromatin accessibility QTLs in human midfetal neural progenitors and/or neurons (76), consistent with the allele-differential regulatory activity we observed. Intriguingly, an early attempt to identify sex-interacting GWAS loci for MDD (77) found suggestive significance for rs1345818, near TMEM161B and MEF2C, a locus which has since been sexagnostically associated to MDD (๑). Our assay did not include the reported sex-interacting GWAS tag, but we identified three variants in LD with rs1345818 that showed sex interactions, confirming that this risk locus indeed has sex-dependent regulatory activity: rs 1814149 (hippocampal $\mathrm{SxG}, \mathrm{FDR}<0.2, \mathrm{R}^{2}$ with rs1345818=0.67), rs5869417 (hippocampal SxG, $\left.\mathrm{FDR}<0.1, \mathrm{R}^{2}=0.21\right)$, and rs6452770 $\left(\right.$ Vglut $\left.^{+} \mathrm{SxG}, \mathrm{FDR}<0.2, \mathrm{R}^{2}=0.69\right)$. 
Downstream analyses aimed at identifying regulatory programs involved across rSNPs provided both support for the rSNP findings themselves, while also identifying novel candidate TFs underlying sex interactions at MDD loci. Our SxG-enriched TF sets were especially rich in sex hormone receptors and interactors, consistent with expectations for an in vivo assay detecting sex interactions, and indicating a role of sex hormone receptors in co-regulation of MDD risk variants. Our hippocampal analyses revealed male-specific roles for $A R$ : male rSNPs were enriched for binding sequences of $Z M I Z 1$, an $A R$ co-activator, while an $A R$ co-repressor, $Z B T B 7 A(78)$, was identified as a shared upstream regulator of these TFs. Notably, ZBTB7A also regulates human non-coding RNA LINC00473 (79), which was recently been demonstrated to have sex-differentiated effects on depressive mouse behaviors when overexpressed in cortex (80). Our TF analyses of P0 SxG rSNPs also identified regulatory programs consistent with the critical period for sexualization of the brain. P0 SxG rSNPs were enriched for TFs interacting with $E S R 1, E S R 2$, and $A R$, consistent with the regulatory landscape necessary for accommodation of sex hormonal signals during the perinatal testosterone surge. Additionally, $P A X 5$ motif disruptions were unique to $\mathrm{P} 0 \mathrm{SxG}$ variants; interestingly the $P A X 5$ motif was recently shown to be enriched in promoters of sex-differentially expressed genes in adult brain (21). Our neurodevelopmental rSNP-enriched TFs likewise recapitulated aspects of recent preclinical studies of sex and depression: or example, P0 female rSNPs were enriched in motifs of endothelial marker $S O X 17$, consistent with demonstration of sex-differential changes in mouse brain vascular permeability after stress $(81)$.

Our assay has several limitations. Notably, our P0/P10 assays could not be compared directly to our adult findings to look for sex-by-age effects, as adult experiments were limited to the hippocampus while developmental assays were brain-wide. Unfortunately, it is impractical to region-specifically deliver AAV9 in utero, and hippocampal morphogenesis is postnatal. 
Likewise, episomal AAV delivery may not capture all regulatory information of a genomic delivery, though benchmark studies indicate a strong correlation (82). Finally, results might be influenced by use of either a different minimal promoter or longer fragments if nearby elements interact with the rSNPs. However, none of these limitations would be expected to create spurious sex effects, indicating the surprising and widespread $\mathrm{SxG}$ interactions are likely to be robust.

The presented in vivo MPRA approach indicates that critical biological and environmental factors involved in brain gene regulation and regulatory variation can be studied using a high-fidelity model of development, cell types, and biological signals. Our approach provides a framework for direct, functional study of psychiatric risk genetics and their interactions with biological and environmental factors that are imperfectly modeled in vitro, including cell type, sex, and brain development. This same approach could be readily used in the future to directly identify variants subject to genetic-environmental interactions with other key psychiatric risk factors, such as early life adversity and chronic stress.

\section{References and Notes}

Acknowledgments:_Scott Lee for assistance with immunofluorescence of pilot hippocampal injections; Michael Vasek, Ph.D. and Lexi Harris for assistance with hippocampal dissections; Ernesto Gonzalez of the Washington University in St. Louis (WU) Hope Center Animal Surgery Core for performing hippocampal AAV9 delivery; EZH Switzerland Viral Vector Facility (VVF) facility for Sanger sequencing and AAV9 packaging of the MPRA library; McDonnell Genome Institute (sequencing), funded by National Institutes of Health grant UL1TR002345; WU Center for Genome Sciences and Systems Biology (sequencing); Barak Cohen, Ph.D., Tony Fisher, Ph.D., Tomás Lagunas, Jr., and Stephen Plassmeyer for insightful discussions and methodologic guidance; WU Center for Cellular Imaging (Axioscan microscope); Biorender (hippocampus experiment schematic); WU Epigenome Browser (RSRC1 locus visualization); and Michael White, Ph.D. and Rachel Rahn, Ph.D. for reviewing the manuscript.

\section{Funding:}

National Institutes of Mental Health (NIMH) grant 5F30MH116654 (BM)

NIMH grant 1R01MH1 16999 (JDD)

Simons Foundation grant 571009 (JDD)

\section{Author contributions:}


Conceptualization: BM, JDD, DS

Methodology: BM, DS, JDD

Investigation: BM, DS

Visualization: BM, DS

Funding acquisition: BM, JDD

Project administration: BM, JDD

Supervision: BM, JDD

Writing - original draft: BM, DS, JDD

Writing - review \& editing: BM, JDD, DS

Competing interests: Authors declare that they have no competing interests.

Data and materials availability: The annotation of library SNPs performed at the time of design are available at https://bitbucket.org/jdlabteam/n2a_atra_mdd_mpra_paper/src/master/Library\%20Design $\% 20$ Epigenomic\%20Annotations/. Code is available at https://bitbucket.org/jdlabteam/paper-resources-mdd-in-vivo-mpras/src. Raw sequencing files and tabulated barcode counts per sample will be made available through GEO accession GSE186348 on publication. Outside datasets used for annotation are detailed in Supplementary Materials.

\section{Supplementary Materials (83-115)}

Materials and Methods

Supplementary Text

Figs. S1 to S7

Tables S1 to S3

References (\#\#-\#\#)

Data S1 to S3

\section{References}

1. R. H. Salk, J. S. Hyde, L. Y. Abramson, Gender Differences in Depression in Representative National Samples: Meta-Analyses of Diagnoses and Symptoms. Psychol Bull. 143, 783-822 (2017).

2. S. M. Marcus, E. A. Young, K. B. Kerber, S. Kornstein, A. H. Farabaugh, J. Mitchell, S. R. Wisniewski, G. K. Balasubramani, M. H. Trivedi, A. J. Rush, Gender differences in depression: Findings from the STAR*D study. J Affect Disorders. 87, 141-150 (2005). 
4. B. Labonté, O. Engmann, I. Purushothaman, C. Menard, J. Wang, C. Tan, J. R. Scarpa, G. Moy, Y.-H. E. Loh, M. Cahill, Z. S. Lorsch, P. J. Hamilton, E. S. Calipari, G. E. Hodes, O. Issler, H. Kronman, M. Pfau, A. L. J. Obradovic, Y. Dong, R. L. Neve, S. Russo, A. Kasarskis, C. Tamminga, N. Mechawar, G. Turecki, B. Zhang, L. Shen, E. J. Nestler, Sex-specific transcriptional signatures in human depression. Nat Med. 23, 1102-1111 (2017).

5. C. Nagy, M. Maitra, A. Tanti, M. Suderman, J.-F. Théroux, M. A. Davoli, K. Perlman, V. Yerko, Y. C. Wang, S. J. Tripathy, P. Pavlidis, N. Mechawar, J. Ragoussis, G. Turecki, Singlenucleus transcriptomics of the prefrontal cortex in major depressive disorder implicates oligodendrocyte precursor cells and excitatory neurons. Nat Neurosci, 1-11 (2020). Adams, E. Agerbo, T. M. Air, T. M. F. Andlauer, S.-A. Bacanu, M. Bækvad-Hansen, A. F. T. Beekman, T. B. Bigdeli, E. B. Binder, D. R. H. Blackwood, J. Bryois, H. N. Buttenschøn, J. Bybjerg-Grauholm, N. Cai, E. Castelao, J. H. Christensen, T.-K. Clarke, J. I. R. Coleman, L. Colodro-Conde, B. Couvy-Duchesne, N. Craddock, G. E. Crawford, C. A. Crowley, H. S. Dashti, G. Davies, I. J. Deary, F. Degenhardt, E. M. Derks, N. Direk, C. V. Dolan, E. C. Dunn, T. C. Eley, N. Eriksson, V. Escott-Price, F. H. F. Kiadeh, H. K. Finucane, A. J. Forstner, J. Frank, H. A. Gaspar, M. Gill, P. Giusti-Rodríguez, F. S. Goes, S. D. Gordon, J. Grove, L. S. Hall, E. Hannon, C. S. Hansen, T. F. Hansen, S. Herms, I. B. Hickie, P. Hoffmann, G. Homuth, C. Horn, J.-J. Hottenga, D. M. Hougaard, M. Hu, C. L. Hyde, M. Ising, R. Jansen, F. Jin, E. Jorgenson, J. A. Knowles, I. S. Kohane, J. Kraft, W. W. Kretzschmar, J. Krogh, Z. Kutalik, J. M. Lane, Y. Li, Y. Li, P. A. Lind, X. Liu, L. Lu, D. J. MacIntyre, D. F. MacKinnon, R. M. Maier, W. Maier, J. Marchini, H. Mbarek, P. McGrath, P. McGuffin, S. E. Medland, D. Mehta, C. M. Middeldorp, E. Mihailov, Y. Milaneschi, L. Milani, J. Mill, F. M. Mondimore, G. W. Montgomery, S. Mostafavi, N. Mullins, M. Nauck, B. Ng, M. G. Nivard, D. R. Nyholt, P. F. O’Reilly, H. Oskarsson, M. J. Owen, J. N. Painter, C. B. Pedersen, M. G. Pedersen, R. E. Peterson, E. Pettersson, W. J. Peyrot, G. Pistis, D. Posthuma, S. M. Purcell, J. A. Quiroz, P. Qvist, J. P. Rice, B. P. Riley, M. Rivera, S. S. Mirza, R. Saxena, R. Schoevers, E. C. Schulte, L. Shen, J. Shi, S. I. Shyn, E. Sigurdsson, G. B. C. Sinnamon, J. H. Smit, D. J. Smith, H. Stefansson, S. Steinberg, C. A. Stockmeier, F. Streit, J. Strohmaier, K. E. Tansey, H. Teismann, A. Teumer, W. Thompson, P. A. Thomson, T. E. Thorgeirsson, C. Tian, M. Traylor, J. Treutlein, V. Trubetskoy, A. G. Uitterlinden, D. Umbricht, S. V. der Auwera, A. M. van Hemert, A. Viktorin, P. M. Visscher, Y. Wang, B. T. Webb, S. M. Weinsheimer, J. Wellmann, G. Willemsen, S. H. Witt, Y. Wu, H. S. Xi, J. Yang, F. Zhang, eQTLGen, 23andMe, V. Arolt, B. T. Baune, K. Berger, D. I. Boomsma, S. Cichon, U. Dannlowski, E. C. J. de Geus, J. R. DePaulo, E. Domenici, K. Domschke, T. Esko, H. J. Grabe, S. P. Hamilton, C. Hayward, A. C. Heath, D. A. Hinds, K. S. Kendler, S. Kloiber, G. Lewis, Q. S. Li, S. Lucae, P. F. A. Madden, P. K. Magnusson, N. G. Martin, A. M. McIntosh, A. Metspalu, O. Mors, P. B. Mortensen, B. MüllerMyhsok, M. Nordentoft, M. M. Nöthen, M. C. O’Donovan, S. A. Paciga, N. L. Pedersen, B. W. J. H. Penninx, R. H. Perlis, D. J. Porteous, J. B. Potash, M. Preisig, M. Rietschel, C. Schaefer, T. G. Schulze, J. W. Smoller, K. Stefansson, H. Tiemeier, R. Uher, H. Völzke, M. M. Weissman, T. Werge, A. R. Winslow, C. M. Lewis, D. F. Levinson, G. Breen, A. D. Børglum, P. F. Sullivan, M. D. D. W. G. of the P. G. Consortium, Genome-wide association analyses identify 44 risk variants and refine the genetic architecture of major depression. Nat Genet. 50, 668-681 (2018). 
7. D. M. Howard, M. J. Adams, T.-K. Clarke, J. D. Hafferty, J. Gibson, M. Shirali, J. R. I. Coleman, S. P. Hagenaars, J. Ward, E. M. Wigmore, C. Alloza, X. Shen, M. C. Barbu, E. Y. Xu, H. C. Whalley, R. E. Marioni, D. J. Porteous, G. Davies, I. J. Deary, G. Hemani, K. Berger, H. Teismann, R. Rawal, V. Arolt, B. T. Baune, U. Dannlowski, K. Domschke, C. Tian, D. A. Hinds, 23 andMe Research Team, M. D. D. W. G. of the P. G. Consortium, M. Trzaskowski, E. M. Byrne, S. Ripke, D. J. Smith, P. F. Sullivan, N. R. Wray, G. Breen, C. M. Lewis, A. M. McIntosh, Genome-wide meta-analysis of depression identifies 102 independent variants and highlights the importance of the prefrontal brain regions. Nat Neurosci. 22, 343-352 (2019).

8. D. F. Levey, M. B. Stein, F. R. Wendt, G. A. Pathak, H. Zhou, M. Aslan, R. Quaden, K. M. Harrington, Y. Z. Nuñez, C. Overstreet, K. Radhakrishnan, G. Sanacora, A. M. McIntosh, J. Shi, S. S. Shringarpure, 23andMe Research Team, M. V. Program, J. Concato, R. Polimanti, J. Gelernter, Bi-ancestral depression GWAS in the Million Veteran Program and meta-analysis in $>1.2$ million individuals highlight new therapeutic directions. Nat Neurosci, 1-10 (2021).

9. G. A. M. Blokland, J. Grove, C.-Y. Chen, C. Cotsapas, S. Tobet, R. Handa, S. W. G. of the P. G. Consortium, D. S. Clair, T. Lencz, B. J. Mowry, S. Periyasamy, M. J. Cairns, P. A. Tooney, J. Q. Wu, B. Kelly, G. Kirov, P. F. Sullivan, A. Corvin, B. P. Riley, T. Esko, L. Milani, E. G. Jönsson, A. Palotie, H. Ehrenreich, M. Begemann, A. Steixner-Kumar, P. C. Sham, N. Iwata, D. R. Weinberger, P. V. Gejman, A. R. Sanders, J. D. Buxbaum, D. Rujescu, I. Giegling, B. Konte, A. M. Hartmann, E. Bramon, R. M. Murray, M. T. Pato, J. Lee, I. Melle, E. Molden, R. A. Ophoff, A. McQuillin, N. J. Bass, R. Adolfsson, A. K. Malhotra, B. D. W. G. of the P. G. Consortium, N. G. Martin, J. M. Fullerton, P. B. Mitchell, P. R. Schofield, A. J. Forstner, F. Degenhardt, S. Schaupp, A. L. Comes, M. Kogevinas, J. Guzman-Parra, A. Reif, F. Streit, L. Sirignano, S. Cichon, M. Grigoroiu-Serbanescu, J. Hauser, J. Lissowska, F. Mayoral, B. MüllerMyhsok, B. Świątkowska, T. G. Schulze, M. M. Nöthen, M. Rietschel, J. Kelsoe, M. Leboyer, S. Jamain, B. Etain, F. Bellivier, J. B. Vincent, M. Alda, C. O’Donovan, P. Cervantes, J. M. Biernacka, M. Frye, S. L. McElroy, L. J. Scott, E. A. Stahl, M. Landén, M. L. Hamshere, O. B. Smeland, S. Djurovic, A. E. Vaaler, O. A. Andreassen, M. D. D. W. G. of the P. G. Consortium, B. T. Baune, T. Air, M. Preisig, R. Uher, D. F. Levinson, M. M. Weissman, J. B. Potash, J. Shi, J. A. Knowles, R. H. Perlis, S. Lucae, D. I. Boomsma, B. W. J. H. Penninx, J.-J. Hottenga, E. J. C. de Geus, G. Willemsen, Y. Milaneschi, H. Tiemeier, H. J. Grabe, A. Teumer, S. V. der Auwera, U. Völker, S. P. Hamilton, P. K. E. Magnusson, A. Viktorin, D. Mehta, N. Mullins, M. J. Adams, G. Breen, A. M. McIntosh, C. M. Lewis, S. D. C.-D. A. G. of the P. G. Consortium, T. L. F. I. for I. P. R. (iPSYCH), D. M. Hougaard, M. Nordentoft, O. Mors, P. B. Mortensen, T. Werge, T. D. Als, A. D. Børglum, T. L. Petryshen, J. W. Smoller, J. M. Goldstein, SexDependent Shared and Non-Shared Genetic Architecture, Across Mood and Psychotic Disorders. Biol Psychiat (2021), doi:10.1016/j.biopsych.2021.02.972.

10. M. Trzaskowski, D. Mehta, W. J. Peyrot, D. Hawkes, D. Davies, D. M. Howard, K. E. Kemper, J. Sidorenko, R. Maier, S. Ripke, M. Mattheisen, B. T. Baune, H. J. Grabe, A. C. Heath, L. Jones, I. Jones, P. A. F. Madden, A. M. McIntosh, G. Breen, C. M. Lewis, A. D. Børglum, P. F. Sullivan, N. G. Martin, K. S. Kendler, D. F. Levinson, N. R. Wray, M. D. D. W. G. of the P. G. Consortium, Quantifying between-cohort and between-sex genetic heterogeneity in major depressive disorder. Am J Medical Genetics Part B Neuropsychiatric Genetics. 180, 439-447 (2019). 
11. J. F. Fullard, M. E. Hauberg, J. Bendl, G. Egervari, M.-D. Cirnaru, S. M. Reach, J. Motl, M. E. Ehrlich, Y. L. Hurd, P. Roussos, An atlas of chromatin accessibility in the adult human brain. Genome Res. 28, 1243-1252 (2018).

12. J. Bryois, N. G. Skene, T. F. Hansen, L. J. A. Kogelman, H. J. Watson, Z. Liu, R. Adan, L. Alfredsson, T. Ando, O. Andreassen, J. Baker, A. Bergen, W. Berrettini, A. Birgegård, J. Boden, I. Boehm, C. Boni, V. B. Perica, H. Brandt, G. Breen, J. Bryois, K. Buehren, C. Bulik, R. Burghardt, M. Cassina, S. Cichon, M. Clementi, J. Coleman, R. Cone, P. Courtet, S. Crawford, S. Crow, J. Crowley, U. Danner, O. Davis, M. de Zwaan, G. Dedoussis, D. Degortes, J. DeSocio, D. Dick, D. Dikeos, C. Dina, M. Dmitrzak-Weglarz, E. D. Martinez, L. Duncan, K. Egberts, S. Ehrlich, G. Escaramís, T. Esko, X. Estivill, A. Farmer, A. Favaro, F. Fernández-Aranda, M. Fichter, K. Fischer, M. Föcker, L. Foretova, A. Forstner, M. Forzan, C. Franklin, S. Gallinger, H. Gaspar, I. Giegling, J. Giuranna, P. Giusti-Rodríquez, F. Gonidakis, S. Gordon, P. Gorwood, M. G. Mayora, J. Grove, S. Guillaume, Y. Guo, H. Hakonarson, K. Halmi, K. Hanscombe, K. Hatzikotoulas, J. Hauser, J. Hebebrand, S. Helder, A. Henders, S. Herms, B. HerpertzDahlmann, W. Herzog, A. Hinney, L. J. Horwood, C. Hübel, L. Huckins, J. Hudson, H. Imgart, H. Inoko, V. Janout, S. Jiménez-Murcia, C. Johnson, J. Jordan, A. Julià, A. Juréus, G. Kalsi, D. Kaminská, A. Kaplan, J. Kaprio, L. Karhunen, A. Karwautz, M. Kas, W. Kaye, J. Kennedy, M. Kennedy, A. Keski-Rahkonen, K. Kiezebrink, Y.-R. Kim, K. Kirk, L. Klareskog, K. Klump, G. P. Knudsen, M. L. Via, M. Landén, J. Larsen, S. L. Hellard, V. Leppä, R. Levitan, D. Li, P. Lichtenstein, L. Lilenfeld, B. D. Lin, J. Lissowska, J. Luykx, P. Magistretti, M. Maj, K. Mannik, S. Marsal, C. Marshall, N. Martin, M. Mattheisen, M. Mattingsdal, S. McDevitt, P. McGuffin, S. Medland, A. Metspalu, I. Meulenbelt, N. Micali, J. Mitchell, K. Mitchell, P. Monteleone, A. M. Monteleone, G. Montgomery, P. B. Mortensen, M. Munn-Chernoff, B. Nacmias, M. Navratilova, C. Norring, I. Ntalla, C. Olsen, R. Ophoff, J. O’Toole, L. Padyukov, A. Palotie, J. Pantel, H. Papezova, R. Parker, J. Pearson, N. Pedersen, L. Petersen, D. Pinto, K. Purves, R. Rabionet, A. Raevuori, N. Ramoz, T. Reichborn-Kjennerud, V. Ricca, S. Ripatti, S. Ripke, F. Ritschel, M. Roberts, A. Rotondo, D. Rujescu, F. Rybakowski, P. Santonastaso, A. Scherag, S. Scherer, U. Schmidt, N. Schork, A. Schosser, J. Seitz, L. Slachtova, P. E. Slagboom, M. S.-O. 't Landt, A. Slopien, S. Sorbi, M. Strober, G. Stuber, P. Sullivan, B. Świątkowska, J. Szatkiewicz, I. Tachmazidou, E. Tenconi, L. Thornton, A. Tortorella, F. Tozzi, J. Treasure, A. Tsitsika, M. Tyszkiewicz-Nwafor, K. Tziouvas, A. van Elburg, E. van Furth, T. Wade, G. Wagner, E. Walton, H. Watson, T. Werge, D. Whiteman, E. Widen, D. B. Woodside, S. Yao, Z. Yilmaz, E. Zeggini, S. Zerwas, S. Zipfel, V. Anttila, V. Artto, A. C. Belin, I. de Boer, D. I. Boomsma, S. Børte, D. I. Chasman, L. Cherkas, A. F. Christensen, B. Cormand, E. Cuenca-Leon, G. DaveySmith, M. Dichgans, C. van Duijn, T. Esko, A. L. Esserlind, M. Ferrari, R. R. Frants, T. Freilinger, N. Furlotte, P. Gormley, L. Griffiths, E. Hamalainen, T. F. Hansen, M. Hiekkala, M. A. Ikram, A. Ingason, M.-R. Järvelin, R. Kajanne, M. Kallela, J. Kaprio, M. Kaunisto, L. J. A. Kogelman, C. Kubisch, M. Kurki, T. Kurth, L. Launer, T. Lehtimaki, D. Lessel, L. Ligthart, N. Litterman, A. van den Maagdenberg, A. Macaya, R. Malik, M. Mangino, G. McMahon, B. Muller-Myhsok, B. M. Neale, C. Northover, D. R. Nyholt, J. Olesen, A. Palotie, P. Palta, L. Pedersen, N. Pedersen, D. Posthuma, P. Pozo-Rosich, A. Pressman, O. Raitakari, M. Schürks, C. Sintas, K. Stefansson, H. Stefansson, S. Steinberg, D. Strachan, G. Terwindt, M. Vila-Pueyo, M. Wessman, B. S. Winsvold, H. Zhao, J. A. Zwart, M. Agee, B. Alipanahi, A. Auton, R. Bell, K. Bryc, S. Elson, P. Fontanillas, N. Furlotte, K. Heilbron, D. Hinds, K. Huber, A. Kleinman, N. Litterman, J. McCreight, M. McIntyre, J. Mountain, E. Noblin, C. Northover, S. Pitts, J. Sathirapongsasuti, O. Sazonova, J. Shelton, S. Shringarpure, C. Tian, J. Tung, V. Vacic, C. 
Wilson, L. Brueggeman, G. Breen, C. M. Bulik, E. Arenas, J. Hjerling-Leffler, P. F. Sullivan, Genetic identification of cell types underlying brain complex traits yields insights into the etiology of Parkinson's disease. Nat Genet, 1-12 (2020).

13. M. E. Hauberg, J. Creus-Muncunill, J. Bendl, A. Kozlenkov, B. Zeng, C. Corwin, S. Chowdhury, H. Kranz, Y. L. Hurd, M. Wegner, A. D. Børglum, S. Dracheva, M. E. Ehrlich, J. F. Fullard, P. Roussos, Common schizophrenia risk variants are enriched in open chromatin regions of human glutamatergic neurons. Nat Commun. 11, 5581 (2020).

14. P. Dong, G. E. Hoffman, P. Apontes, J. Bendl, S. Rahman, M. B. Fernando, B. Zeng, J. M. Vicari, W. Zhang, K. Girdhar, K. G. Townsley, R. Misir, K. J. Brennand, V. Haroutunian, G. Voloudakis, J. F. Fullard, P. Roussos, Biorxiv, in press, doi:10.1101/2021.05.14.443421.

15. M. Song, M.-P. Pebworth, X. Yang, A. Abnousi, C. Fan, J. Wen, J. D. Rosen, M. N. K. Choudhary, X. Cui, I. R. Jones, S. Bergenholtz, U. C. Eze, I. Juric, B. Li, L. Maliskova, J. Lee, W. Liu, A. A. Pollen, Y. Li, T. Wang, M. Hu, A. R. Kriegstein, Y. Shen, Cell-type-specific 3D epigenomes in the developing human cortex. Nature, 1-6 (2020).

16. D. Polioudakis, L. de la Torre-Ubieta, J. Langerman, A. G. Elkins, X. Shi, J. L. Stein, C. K. Vuong, S. Nichterwitz, M. Gevorgian, C. K. Opland, D. Lu, W. Connell, E. K. Ruzzo, J. K. Lowe, T. Hadzic, F. I. Hinz, S. Sabri, W. E. Lowry, M. B. Gerstein, K. Plath, D. H. Geschwind, A Single-Cell Transcriptomic Atlas of Human Neocortical Development during Mid-gestation. Neuron. 103, 785-801.e8 (2019).

17. L. Schmaal, D. J. Veltman, T. G. M. van Erp, P. G. Sämann, T. Frodl, N. Jahanshad, E. Loehrer, H. Tiemeier, A. Hofman, W. J. Niessen, M. W. Vernooij, M. A. Ikram, K. Wittfeld, H. J. Grabe, A. Block, K. Hegenscheid, H. Völzke, D. Hoehn, M. Czisch, J. Lagopoulos, S. N. Hatton, I. B. Hickie, R. Goya-Maldonado, B. Krämer, O. Gruber, B. Couvy-Duchesne, M. E. Rentería, L. T. Strike, N. T. Mills, G. I. de Zubicaray, K. L. McMahon, S. E. Medland, N. G. Martin, N. A. Gillespie, M. J. Wright, G. B. Hall, G. M. MacQueen, E. M. Frey, A. Carballedo, L. S. van Velzen, M. J. van Tol, N. J. van der Wee, I. M. Veer, H. Walter, K. Schnell, E. Schramm, C. Normann, D. Schoepf, C. Konrad, B. Zurowski, T. Nickson, A. M. McIntosh, M. Papmeyer, H. C. Whalley, J. E. Sussmann, B. R. Godlewska, P. J. Cowen, F. H. Fischer, M. Rose, B. W. J. H. Penninx, P. M. Thompson, D. P. Hibar, Subcortical brain alterations in major depressive disorder: findings from the ENIGMA Major Depressive Disorder working group. Mol Psychiatr. 21, 806-812 (2015).

18. J. M. Zhang, L. Tonelli, W. T. Regenold, M. M. McCarthy, Effects of neonatal flutamide treatment on hippocampal neurogenesis and synaptogenesis correlate with depression-like behaviors in preadolescent male rats. Neuroscience. 169, 544-554 (2010).

19. C. Isgor, D. R. Sengelaub, Effects of neonatal gonadal steroids on adult CA3 pyramidal neuron dendritic morphology and spatial memory in rats. J Neurobiol. 55, 179-190 (2003).

20. M. A. Kohli, S. Lucae, P. G. Saemann, M. V. Schmidt, A. Demirkan, K. Hek, D. Czamara, M. Alexander, D. Salyakina, S. Ripke, D. Hoehn, M. Specht, A. Menke, J. Hennings, A. Heck, C. Wolf, M. Ising, S. Schreiber, M. Czisch, M. B. Müller, M. Uhr, T. Bettecken, A. Becker, J. 
Schramm, M. Rietschel, W. Maier, B. Bradley, K. J. Ressler, M. M. Nöthen, S. Cichon, I. W. Craig, G. Breen, C. M. Lewis, A. Hofman, H. Tiemeier, C. M. van Duijn, F. Holsboer, B. Müller-Myhsok, E. B. Binder, The Neuronal Transporter Gene SLC6A15 Confers Risk to Major Depression. Neuron. 70, 252-265 (2011).

21. M. Oliva, M. Muñoz-Aguirre, S. Kim-Hellmuth, V. Wucher, A. D. H. Gewirtz, D. J. Cotter, P. Parsana, S. Kasela, B. Balliu, A. Viñuela, S. E. Castel, P. Mohammadi, F. Aguet, Y. Zou, E. A. Khramtsova, A. D. Skol, D. Garrido-Martín, F. Reverter, A. Brown, P. Evans, E. R. Gamazon, A. Payne, R. Bonazzola, A. N. Barbeira, A. R. Hamel, A. Martinez-Perez, J. M. Soria, Gte. Consortium §, B. L. Pierce, M. Stephens, E. Eskin, E. T. Dermitzakis, A. V. Segrè, H. K. Im, B. E. Engelhardt, K. G. Ardlie, S. B. Montgomery, A. J. Battle, T. Lappalainen, R. Guigó, B. E. Stranger, The impact of sex on gene expression across human tissues. Science. 369, eaba3066 (2020).

22. R. Tewhey, D. Kotliar, D. S. Park, B. Liu, S. Winnicki, S. K. Reilly, K. G. Andersen, T. S. Mikkelsen, E. S. Lander, S. F. Schaffner, P. C. Sabeti, Direct Identification of Hundreds of Expression-Modulating Variants using a Multiplexed Reporter Assay. Cell. 165, 1519-1529 (2016).

23. X. Lu, X. Chen, C. Forney, O. Donmez, D. Miller, S. Parameswaran, T. Hong, Y. Huang, M. Pujato, T. Cazares, E. R. Miraldi, J. P. Ray, C. G. de Boer, J. B. Harley, M. T. Weirauch, L. C. Kottyan, Global discovery of lupus genetic risk variant allelic enhancer activity. Nat Commun. 12, 1611 (2021).

24. J. Choi, T. Zhang, A. Vu, J. Ablain, M. M. Makowski, L. M. Colli, M. Xu, R. C. Hennessey, J. Yin, H. Rothschild, C. Gräwe, M. A. Kovacs, K. M. Funderburk, M. Brossard, J. Taylor, B. Pasaniuc, R. Chari, S. J. Chanock, C. J. Hoggart, F. Demenais, J. H. Barrett, M. H. Law, M. M. Iles, K. Yu, M. Vermeulen, L. I. Zon, K. M. Brown, Massively parallel reporter assays of melanoma risk variants identify MX2 as a gene promoting melanoma. Nat Commun. 11, 2718 (2020).

25. R. N. Doan, B.-I. Bae, B. Cubelos, C. Chang, A. A. Hossain, S. Al-Saad, N. M. Mukaddes, O. Oner, M. Al-Saffar, S. Balkhy, G. G. Gascon, H. M. C. for Autism, M. Nieto, C. A. Walsh, Mutations in Human Accelerated Regions Disrupt Cognition and Social Behavior. Cell. 167, $30 \quad 341-354 . e 12(2016)$.

26. B. Mulvey, J. D. Dougherty, Transcriptional-regulatory convergence across functional MDD risk variants identified by massively parallel reporter assays. Transl Psychiat. 11, 403 (2021).

27. J. T. Lambert, L. Su-Feher, K. Cichewicz, T. L. Warren, I. Zdilar, Y. Wang, K. J. Lim, J. Haigh, S. J. Morse, C. P. Canales, T. W. Stradleigh, E. Castillo, V. Haghani, S. Moss, H. Parolini, D. Quintero, D. Shrestha, D. Vogt, L. C. Byrne, A. S. Nord, Biorxiv, in press, doi:10.1101/2021.01.15.426772.

28. S. Q. Shen, J. S. Kim-Han, L. Cheng, D. Xu, O. Gokcumen, A. E. O. Hughes, C. A. Myers, J. C. Corbo, A candidate causal variant underlying both higher intelligence and increased risk of bipolar disorder. Biorxiv, 580258 (2019). 
29. D. M. Werling, S. Pochareddy, J. Choi, J.-Y. An, B. Sheppard, M. Peng, Z. Li, C. Dastmalchi, G. Santpere, A. M. M. Sousa, A. T. N. Tebbenkamp, N. Kaur, F. O. Gulden, M. S. Breen, L. Liang, M. C. Gilson, X. Zhao, S. Dong, L. Klei, A. E. Cicek, J. D. Buxbaum, H. AdleBiassette, J.-L. Thomas, K. A. Aldinger, D. R. O’Day, I. A. Glass, N. A. Zaitlen, M. E. Talkowski, K. Roeder, M. W. State, B. Devlin, S. J. Sanders, N. Sestan, Whole-Genome and RNA Sequencing Reveal Variation and Transcriptomic Coordination in the Developing Human Prefrontal Cortex. Cell Reports. 31, 107489 (2020).

30. M. R. Kouakou, D. Cameron, E. Hannon, E. L. Dempster, J. Mill, M. J. Hill, N. J. Bray, Sites of active gene regulation in the prenatal frontal cortex and their role in neuropsychiatric disorders. Am J Medical Genetics Part B Neuropsychiatric Genetics (2021), doi:10.1002/ajmg.b.32877.

31. A. J. Schork, H. Won, V. Appadurai, R. Nudel, M. Gandal, O. Delaneau, M. R. Christiansen, D. M. Hougaard, M. Bækved-Hansen, J. Bybjerg-Grauholm, M. G. Pedersen, E. Agerbo, C. B. Pedersen, B. M. Neale, M. J. Daly, N. R. Wray, M. Nordentoft, O. Mors, A. D. Børglum, P. B. Mortensen, A. Buil, W. K. Thompson, D. H. Geschwind, T. Werge, A genome-wide association study of shared risk across psychiatric disorders implicates gene regulation during fetal neurodevelopment. Nat Neurosci. 22, 353-361 (2019).

32. C.-D. G. of the P. G. Consortium, P. H. Lee, V. Anttila, H. Won, Y.-C. A. Feng, J. Rosenthal, Z. Zhu, E. M. Tucker-Drob, M. G. Nivard, A. D. Grotzinger, D. Posthuma, M. M.-J. Wang, D. Yu, E. A. Stahl, R. K. Walters, R. J. L. Anney, L. E. Duncan, T. Ge, R. Adolfsson, T. Banaschewski, S. Belangero, E. H. Cook, G. Coppola, E. M. Derks, P. J. Hoekstra, J. Kaprio, A. Keski-Rahkonen, G. Kirov, H. R. Kranzler, J. J. Luykx, L. A. Rohde, C. C. Zai, E. Agerbo, M. J. Arranz, P. Asherson, M. Bækvad-Hansen, G. Baldursson, M. Bellgrove, R. A. Belliveau, J. Buitelaar, C. L. Burton, J. Bybjerg-Grauholm, M. Casas, F. Cerrato, K. Chambert, C. Churchhouse, B. Cormand, J. Crosbie, S. Dalsgaard, D. Demontis, A. E. Doyle, A. Dumont, J. Elia, J. Grove, O. O. Gudmundsson, J. Haavik, H. Hakonarson, C. S. Hansen, C. A. Hartman, Z. Hawi, A. Hervás, D. M. Hougaard, D. P. Howrigan, H. Huang, J. Kuntsi, K. Langley, K.-P. Lesch, P. W. L. Leung, S. K. Loo, J. Martin, A. R. Martin, J. J. McGough, S. E. Medland, J. L. Moran, O. Mors, P. B. Mortensen, R. D. Oades, D. S. Palmer, C. B. Pedersen, M. G. Pedersen, T. Peters, T. Poterba, J. B. Poulsen, J. A. Ramos-Quiroga, A. Reif, M. Ribasés, A. Rothenberger, P. Rovira, C. Sánchez-Mora, F. K. Satterstrom, R. Schachar, M. S. Artigas, S. Steinberg, H. Stefansson, P. Turley, G. B. Walters, 23andMe Research Team, T. Werge, T. Zayats, D. E. Arking, F. Bettella, J. D. Buxbaum, J. H. Christensen, R. L. Collins, H. Coon, S. D. Rubeis, R. Delorme, D. E. Grice, T. F. Hansen, P. A. Holmans, S. Hope, C. M. Hultman, L. Klei, C. LaddAcosta, P. Magnusson, T. Nærland, M. Nyegaard, D. Pinto, P. Qvist, K. Rehnström, A. Reichenberg, J. Reichert, K. Roeder, G. A. Rouleau, E. Saemundsen, S. J. Sanders, S. Sandin, B. S. Pourcain, K. Stefansson, J. S. Sutcliffe, M. E. Talkowski, L. A. Weiss, A. J. Willsey, I. Agartz, H. Akil, D. Albani, M. Alda, T. D. Als, A. Anjorin, L. Backlund, N. Bass, M. Bauer, B. T. Baune, F. Bellivier, S. E. Bergen, W. H. Berrettini, J. M. Biernacka, D. H. R. Blackwood, E. Bøen, M. Budde, W. Bunney, M. Burmeister, W. Byerley, E. M. Byrne, S. Cichon, T.-K. Clarke, J. R. I. Coleman, N. Craddock, D. Curtis, P. M. Czerski, A. M. Dale, N. Dalkner, U. Dannlowski, F. Degenhardt, A. D. Florio, T. Elvsåshagen, B. Etain, S. B. Fischer, A. J. Forstner, L. Forty, J. Frank, M. Frye, J. M. Fullerton, K. Gade, H. A. Gaspar, E. S. Gershon, M. Gill, F. S. Goes, S. D. Gordon, K. Gordon-Smith, M. J. Green, T. A. Greenwood, M. Grigoroiu- 
Serbanescu, J. Guzman-Parra, J. Hauser, M. Hautzinger, U. Heilbronner, S. Herms, P. Hoffmann, D. Holland, S. Jamain, I. Jones, L. A. Jones, R. Kandaswamy, J. R. Kelsoe, J. L. Kennedy, O. K. Joachim, S. Kittel-Schneider, M. Kogevinas, A. C. Koller, C. Lavebratt, C. M. Lewis, Q. S. Li, J. Lissowska, L. M. O. Loohuis, S. Lucae, A. Maaser, U. F. Malt, N. G. Martin, L. Martinsson, S. L. McElroy, F. J. McMahon, A. McQuillin, I. Melle, A. Metspalu, V. Millischer, P. B. Mitchell, G. W. Montgomery, G. Morken, D. W. Morris, B. Müller-Myhsok, N. Mullins, R. M. Myers, C. M. Nievergelt, M. Nordentoft, A. N. Adolfsson, M. M. Nöthen, R. A. Ophoff, M. J. Owen, S. A. Paciga, C. N. Pato, M. T. Pato, R. H. Perlis, A. Perry, J. B. Potash, C. S. Reinbold, M. Rietschel, M. Rivera, M. Roberson, M. Schalling, P. R. Schofield, T. G. Schulze, L. J. Scott, A. Serretti, E. Sigurdsson, O. B. Smeland, E. Stordal, F. Streit, J. Strohmaier, T. E. Thorgeirsson, J. Treutlein, G. Turecki, A. E. Vaaler, E. Vieta, J. B. Vincent, Y. Wang, S. H. Witt, P. Zandi, R. A. H. Adan, L. Alfredsson, T. Ando, H. Aschauer, J. H. Baker, V. Bencko, A. W. Bergen, A. Birgegård, V. B. Perica, H. Brandt, R. Burghardt, L. Carlberg, M. Cassina, M. Clementi, P. Courtet, S. Crawford, S. Crow, J. J. Crowley, U. N. Danner, O. S. P. Davis, D. Degortes, J. E. DeSocio, D. M. Dick, C. Dina, E. Docampo, K. Egberts, S. Ehrlich, T. Espeseth, F. Fernández-Aranda, M. M. Fichter, L. Foretova, M. Forzan, G. Gambaro, I. Giegling, F. Gonidakis, P. Gorwood, M. G. Mayora, Y. Guo, K. A. Halmi, K. Hatzikotoulas, J. Hebebrand, S. G. Helder, B. Herpertz-Dahlmann, W. Herzog, A. Hinney, H. Imgart, S. JiménezMurcia, C. Johnson, J. Jordan, A. Julià, D. Kaminská, L. Karhunen, A. Karwautz, M. J. H. Kas, W. H. Kaye, M. A. Kennedy, Y.-R. Kim, L. Klareskog, K. L. Klump, G. P. S. Knudsen, M. Landén, S. L. Hellard, R. D. Levitan, D. Li, P. Lichtenstein, M. Maj, S. Marsal, S. McDevitt, J. Mitchell, P. Monteleone, A. M. Monteleone, M. A. Munn-Chernoff, B. Nacmias, M. Navratilova, J. K. O’Toole, L. Padyukov, J. Pantel, H. Papezova, R. Rabionet, A. Raevuori, N. Ramoz, T. Reichborn-Kjennerud, V. Ricca, M. Roberts, D. Rujescu, F. Rybakowski, A. Scherag, U. Schmidt, J. Seitz, L. Slachtova, M. C. T. S.-O. Landt, A. Slopien, S. Sorbi, L. Southam, M. Strober, A. Tortorella, F. Tozzi, J. Treasure, K. Tziouvas, A. A. van Elburg, T. D. Wade, G. Wagner, E. Walton, H. J. Watson, H.-E. Wichmann, D. B. Woodside, E. Zeggini, S. Zerwas, S. Zipfel, M. J. Adams, T. F. M. Andlauer, K. Berger, E. B. Binder, D. I. Boomsma, E. Castelao, L. Colodro-Conde, N. Direk, A. R. Docherty, E. Domenici, K. Domschke, E. C. Dunn, J. C. Foo, E. J. C. de. Geus, H. J. Grabe, S. P. Hamilton, C. Horn, J.-J. Hottenga, D. Howard, M. Ising, S. Kloiber, D. F. Levinson, G. Lewis, P. K. E. Magnusson, H. Mbarek, C. M. Middeldorp, S. Mostafavi, D. R. Nyholt, B. WJH. Penninx, R. E. Peterson, G. Pistis, D. J. Porteous, M. Preisig, J. A. Quiroz, C. Schaefer, E. C. Schulte, J. Shi, D. J. Smith, P. A. Thomson, H. Tiemeier, R. Uher, S. van der Auwera, M. M. Weissman, M. Alexander, M. Begemann, E. Bramon, N. G. Buccola, M. J. Cairns, D. Campion, V. J. Carr, C. R. Cloninger, D. Cohen, D. A. Collier, A. Corvin, L. E. DeLisi, G. Donohoe, F. Dudbridge, J. Duan, R. Freedman, P. V. Gejman, V. Golimbet, S. Godard, H. Ehrenreich, A. M. Hartmann, F. A. Henskens, M. Ikeda, N. Iwata, A. V. Jablensky, I. Joa, E. G. Jönsson, B. J. Kelly, J. Knight, B. Konte, C. Laurent-Levinson, J. Lee, T. Lencz, B. Lerer, C. M. Loughland, A. K. Malhotra, J. Mallet, C. McDonald, M. Mitjans, B. J. Mowry, K. C. Murphy, R. M. Murray, F. A. O’Neill, S.-Y. Oh, A. Palotie, C. Pantelis, A. E. Pulver, P. E. I. Consortium, T. L. Petryshen, D. J. Quested, B. Riley, A. R. Sanders, U. Schall, S. G. Schwab, R. J. Scott, P. C. Sham, J. M. Silverman, K. Sim, A. A. Steixner, P. A. Tooney, J. van Os, M. P. Vawter, D. Walsh, M. Weiser, D. B. Wildenauer, N. M. Williams, B. K. Wormley, W. T. C.-C. Consortium, F. Zhang, C. Androutsos, P. D. Arnold, C. L. Barr, C. Barta, K. Bey, O. J. Bienvenu, D. W. Black, L. W. Brown, C. Budman, D. Cath, K.-A. Cheon, V. Ciullo, B. J. Coffey, D. Cusi, L. K. Davis, D. Denys, C. Depienne, A. Dietrich, V. Eapen, P. Falkai, T. V. Fernandez, B. Garcia-Delgar, D. A. Geller, D. L. Gilbert, M. A. Grados, E. Greenberg, E. Grünblatt, J. Hagstrøm, G. L. Hanna, A. Hartmann, T. Hedderly, G. A. Heiman, I. Heyman, H. J. 
Hong, A. Huang, C. Huyser, L. Ibanez-Gomez, E. A. Khramtsova, Y. K. Kim, Y.-S. Kim, R. A. King, Y.-J. Koh, A. Konstantinidis, S. Kook, S. Kuperman, B. L. Leventhal, C. Lochner, A. G. Ludolph, M. Madruga-Garrido, I. Malaty, A. Maras, J. T. McCracken, I. A. Meijer, P. Mir, A. Morer, K. R. Müller-Vahl, A. Münchau, T. L. Murphy, A. Naarden, P. Nagy, G. Nestadt, P. S. Nestadt, H. Nicolini, E. L. Nurmi, M. S. Okun, P. Paschou, F. Piras, F. Piras, C. Pittenger, K. J. Plessen, M. A. Richter, R. Rizzo, M. Robertson, V. Roessner, S. Ruhrmann, J. F. Samuels, P. Sandor, M. Schlögelhofer, E.-Y. Shin, H. Singer, D.-H. Song, J. Song, G. Spalletta, D. J. Stein, S. E. Stewart, E. A. Storch, B. Stranger, M. Stuhrmann, Z. Tarnok, J. A. Tischfield, J. Tübing, F. Visscher, N. Vulink, M. Wagner, S. Walitza, S. Wanderer, M. Woods, Y. Worbe, G. Zai, S. H. Zinner, P. F. Sullivan, B. Franke, M. J. Daly, C. M. Bulik, A. M. McIntosh, M. C. O’Donovan, A. Zheutlin, O. A. Andreassen, A. D. Børglum, G. Breen, H. J. Edenberg, A. H. Fanous, S. V. Faraone, J. Gelernter, C. A. Mathews, M. Mattheisen, K. S. Mitchell, M. C. Neale, J. I. Nurnberger, S. Ripke, S. L. Santangelo, J. M. Scharf, M. B. Stein, L. M. Thornton, J. T. R. Walters, N. R. Wray, D. H. Geschwind, B. M. Neale, K. S. Kendler, J. W. Smoller, Genomic Relationships, Novel Loci, and Pleiotropic Mechanisms across Eight Psychiatric Disorders. Cell. 179, 1469-1482.e11 (2019).

33. A. P. Arnold, S. M. Breedlove, Organizational and activational effects of sex steroids on brain and behavior: A reanalysis. Horm Behav. 19, 469-498 (1985).

34. S. Q. Shen, C. A. Myers, A. E. O. Hughes, L. C. Byrne, J. G. Flannery, J. C. Corbo, Massively parallel cis -regulatory analysis in the mammalian central nervous system. Genome Res. 26, 238-255 (2016).

35. S. Hrvatin, C. P. Tzeng, M. A. Nagy, H. Stroud, C. Koutsioumpa, O. F. Wilcox, E. G. Assad, J. Green, C. D. Harvey, E. C. Griffith, M. E. Greenberg, A scalable platform for the development of cell-type-specific viral drivers. Elife. 8, e48089 (2019). viral injection of the neonatal mouse brain for persistent and widespread neuronal transduction. $J$ Vis Exp Jove, 51863 (2014).

37. J. D. Dougherty, E. I. Fomchenko, A. A. Akuffo, E. Schmidt, K. Y. Helmy, E. Bazzoli, C. W. Brennan, E. C. Holland, A. Milosevic, Candidate pathways for promoting differentiation or quiescence of oligodendrocyte progenitor-like cells in glioma. Cancer Res. 72, 4856-68 (2012).

38. J. A. Harris, K. E. Hirokawa, S. A. Sorensen, H. Gu, M. Mills, L. L. Ng, P. Bohn, M. Mortrud, B. Ouellette, J. Kidney, K. A. Smith, C. Dang, S. Sunkin, A. Bernard, S. W. Oh, L. Madisen, H. Zeng, Anatomical characterization of Cre driver mice for neural circuit mapping and manipulation. Front Neural Circuit. 8, 76 (2014). Li, Y.-G. Yao, C. Zhang, X.-J. Luo, 23andMe Research Team7, Common variants on 6q16.2, $12 q 24.31$ and 16p13.3 are associated with major depressive disorder. Neuropsychopharmacol. 43, 2146-2153 (2018). 
40. C. L. Hyde, M. W. Nagle, C. Tian, X. Chen, S. A. Paciga, J. R. Wendland, J. Y. Tung, D. A. Hinds, R. H. Perlis, A. R. Winslow, Identification of 15 genetic loci associated with risk of major depression in individuals of European descent. Nat Genet. 48, 1031-1036 (2016).

41. R. A. Power, K. E. Tansey, H. N. Buttenschøn, S. Cohen-Woods, T. Bigdeli, L. S. Hall, Z. Kutalik, S. H. Lee, S. Ripke, S. Steinberg, A. Teumer, A. Viktorin, N. R. Wray, V. Arolt, B. T. Baune, D. I. Boomsma, A. D. Børglum, E. M. Byrne, E. Castelao, N. Craddock, I. W. Craig, U. Dannlowski, I. J. Deary, F. Degenhardt, A. J. Forstner, S. D. Gordon, H. J. Grabe, J. Grove, S. P. Hamilton, C. Hayward, A. C. Heath, L. J. Hocking, G. Homuth, J. J. Hottenga, S. Kloiber, J. Krogh, M. Landén, M. Lang, D. F. Levinson, P. Lichtenstein, S. Lucae, D. J. MacIntyre, P. Madden, P. K. E. Magnusson, N. G. Martin, A. M. McIntosh, C. M. Middeldorp, Y. Milaneschi, G. W. Montgomery, O. Mors, B. Müller-Myhsok, D. R. Nyholt, H. Oskarsson, M. J. Owen, S. Padmanabhan, B. W. J. H. Penninx, M. L. Pergadia, D. J. Porteous, J. B. Potash, M. Preisig, M. Rivera, J. Shi, S. I. Shyn, E. Sigurdsson, J. H. Smit, B. H. Smith, H. Stefansson, K. Stefansson, J. Strohmaier, P. F. Sullivan, P. Thomson, T. E. Thorgeirsson, S. V. der Auwera, M. M. Weissman, C. C. Consortium CARDIoGRAM Consortium, GERAD1, G. Breen, C. M. Lewis, Genomewide Association for Major Depression Through Age at Onset Stratification: Major Depressive Disorder Working Group of the Psychiatric Genomics Consortium. Biol Psychiat. 81, 325-335 (2017).

42. N. Cai, T. B. Bigdeli, W. Kretzschmar, Y. Li, J. Liang, L. Song, J. Hu, Q. Li, W. Jin, Z. Hu, G. Wang, L. Wang, P. Qian, Y. Liu, T. Jiang, Y. Lu, X. Zhang, Y. Yin, Y. Li, X. Xu, J. Gao, M. Reimers, T. Webb, B. Riley, S. Bacanu, R. E. Peterson, Y. Chen, H. Zhong, Z. Liu, G. Wang, J. Sun, H. Sang, G. Jiang, X. Zhou, Y. Li, Y. Li, W. Zhang, X. Wang, X. Fang, R. Pan, G. Miao, Q. Zhang, J. Hu, F. Yu, B. Du, W. Sang, K. Li, G. Chen, M. Cai, L. Yang, D. Yang, B. Ha, X. Hong, H. Deng, G. Li, K. Li, Y. Song, S. Gao, J. Zhang, Z. Gan, H. Meng, J. Pan, C. Gao, K. Zhang, N. Sun, Y. Li, Q. Niu, Y. Zhang, T. Liu, C. Hu, Z. Zhang, L. Lv, J. Dong, X. Wang, M. Tao, X. Wang, J. Xia, H. Rong, Q. He, T. Liu, G. Huang, Q. Mei, Z. Shen, Y. Liu, J. Shen, T. Tian, X. Liu, W. Wu, D. Gu, G. Fu, J. Shi, Y. Chen, X. Gan, L. Liu, L. Wang, F. Yang, E. Cong, J. Marchini, H. Yang, J. Wang, S. Shi, R. Mott, Q. Xu, J. Wang, K. S. Kendler, J. Flint, Sparse whole-genome sequencing identifies two loci for major depressive disorder. Nature. 523, 588591 (2015).

43. H. Ren, C. Fabbri, R. Uher, M. Rietschel, O. Mors, N. Henigsberg, J. Hauser, A. Zobel, W. Maier, M. Z. Dernovsek, D. Souery, A. Cattaneo, G. Breen, I. W. Craig, A. E. Farmer, P. McGuffin, C. M. Lewis, K. J. Aitchison, Genes associated with anhedonia: a new analysis in a large clinical trial (GENDEP). Transl Psychiat. 8, 150 (2018).

44. J. Grove, S. Ripke, T. D. Als, M. Mattheisen, R. K. Walters, H. Won, J. Pallesen, E. Agerbo, O. A. Andreassen, R. Anney, S. Awashti, R. Belliveau, F. Bettella, J. D. Buxbaum, J. BybjergGrauholm, M. Bækvad-Hansen, F. Cerrato, K. Chambert, J. H. Christensen, C. Churchhouse, K. Dellenvall, D. Demontis, S. D. Rubeis, B. Devlin, S. Djurovic, A. L. Dumont, J. I. Goldstein, C. S. Hansen, M. E. Hauberg, M. V. Hollegaard, S. Hope, D. P. Howrigan, H. Huang, C. M. Hultman, L. Klei, J. Maller, J. Martin, A. R. Martin, J. L. Moran, M. Nyegaard, T. Nærland, D. S. Palmer, A. Palotie, C. B. Pedersen, M. G. Pedersen, T. dPoterba, J. B. Poulsen, B. S. Pourcain, P. Qvist, K. Rehnström, A. Reichenberg, J. Reichert, E. B. Robinson, K. Roeder, P. Roussos, E. Saemundsen, S. Sandin, F. K. Satterstrom, G. D. Smith, H. Stefansson, S. Steinberg, C. R. 
Stevens, P. F. Sullivan, P. Turley, G. B. Walters, X. Xu, A. S. D. W. G. of the P. G. Consortium, BUPGEN, M. D. D. W. G. of the P. G. Consortium, 23andMe Research Team, K. Stefansson, D. H. Geschwind, M. Nordentoft, D. M. Hougaard, T. Werge, O. Mors, P. B. Mortensen, B. M. Neale, M. J. Daly, A. D. Børglum, Identification of common genetic risk variants for autism spectrum disorder. Nat Genet. 51, 431-444 (2019).

45. D. J. Smith, V. Escott-Price, G. Davies, M. E. S. Bailey, L. Colodro-Conde, J. Ward, A. Vedernikov, R. Marioni, B. Cullen, D. Lyall, S. P. Hagenaars, D. C. M. Liewald, M. Luciano, C. R. Gale, S. J. Ritchie, C. Hayward, B. Nicholl, B. Bulik-Sullivan, M. Adams, B. CouvyDuchesne, N. Graham, D. Mackay, J. Evans, B. H. Smith, D. J. Porteous, S. E. Medland, N. G. Martin, P. Holmans, A. M. McIntosh, J. P. Pell, I. J. Deary, M. C. O’Donovan, Genome-wide analysis of over 106000 individuals identifies 9 neuroticism-associated loci. Mol Psychiatr. 21, 1644 (2016).

46. M. Luciano, S. P. Hagenaars, G. Davies, W. D. Hill, T.-K. Clarke, M. Shirali, S. E. Harris, R. E. Marioni, D. C. Liewald, C. Fawns-Ritchie, M. J. Adams, D. M. Howard, C. M. Lewis, C. R. Gale, A. M. McIntosh, I. J. Deary, Association analysis in over 329,000 individuals identifies 116 independent variants influencing neuroticism. Nat Genet. 50, 6-11 (2017).

47. S. M. Meier, K. Trontti, K. L. Purves, T. D. Als, J. Grove, M. Laine, M. G. Pedersen, J. Bybjerg-Grauholm, M. Bækved-Hansen, E. Sokolowska, P. B. Mortensen, D. M. Hougaard, T. Werge, M. Nordentoft, G. Breen, A. D. Børglum, T. C. Eley, I. Hovatta, M. Mattheisen, O. Mors, Genetic Variants Associated With Anxiety and Stress-Related Disorders. Jama Psychiat. 76, 924-932 (2019).

48. J. Ward, E. M. Tunbridge, C. Sandor, L. M. Lyall, A. Ferguson, R. J. Strawbridge, D. M. Lyall, B. Cullen, N. Graham, K. J. A. Johnston, C. Webber, V. Escott-Price, M. O’Donovan, J. P. Pell, M. E. S. Bailey, P. J. Harrison, D. J. Smith, The genomic basis of mood instability: identification of 46 loci in 363,705 UK Biobank participants, genetic correlation with psychiatric disorders, and association with gene expression and function. Mol Psychiatr, 1-9 (2019).

49. M. A. White, C. A. Myers, J. C. Corbo, B. A. Cohen, Massively parallel in vivo enhancer assay reveals that highly local features determine the cis-regulatory function of ChIP-seq peaks. Proc National Acad Sci. 110, 11952-11957 (2013).

50. F. Inoue, A. Kreimer, T. Ashuach, N. Ahituv, N. Yosef, Identification and Massively Parallel Characterization of Regulatory Elements Driving Neural Induction. Cell Stem Cell (2019), doi:10.1016/j.stem.2019.09.010.

51. J. D. Storey, R. Tibshirani, Statistical significance for genomewide studies. Proc National Acad Sci. 100, 9440-9445 (2003).

52. A. E. Jaffe, D. J. Hoeppner, T. Saito, L. Blanpain, J. Ukaigwe, E. E. Burke, L. ColladoTorres, R. Tao, K. Tajinda, K. R. Maynard, M. N. Tran, K. Martinowich, A. Deep-Soboslay, J. H. Shin, J. E. Kleinman, D. R. Weinberger, M. Matsumoto, T. M. Hyde, Profiling gene expression in the human dentate gyrus granule cell layer reveals insights into schizophrenia and its genetic risk. Nat Neurosci. 23, 510-519 (2020). 
53. K. M. Coleman, V. Lam, B. M. Jaber, R. B. Lanz, C. L. Smith, SRA coactivation of estrogen receptor-alpha is phosphorylation-independent, and enhances 4-hydroxytamoxifen agonist activity. Biochem Bioph Res Co. 323, 332-8 (2004).

54. D. Wang, S. Liu, J. Warrell, H. Won, X. Shi, F. C. P. Navarro, D. Clarke, M. Gu, P. Emani, Y. T. Yang, M. Xu, M. J. Gandal, S. Lou, J. Zhang, J. J. Park, C. Yan, S. K. Rhie, K. Manakongtreecheep, H. Zhou, A. Nathan, M. Peters, E. Mattei, D. Fitzgerald, T. Brunetti, J. Moore, Y. Jiang, K. Girdhar, G. E. Hoffman, S. Kalayci, Z. H. Gümüş, G. E. Crawford, P. Consortium, P. Roussos, S. Akbarian, A. E. Jaffe, K. P. White, Z. Weng, N. Sestan, D. H. Geschwind, J. A. Knowles, M. B. Gerstein, A. E. Ashley-Koch, G. E. Crawford, M. E. Garrett, L. Song, A. Safi, G. D. Johnson, G. A. Wray, T. E. Reddy, F. S. Goes, P. Zandi, J. Bryois, A. E. Jaffe, A. J. Price, N. A. Ivanov, L. Collado-Torres, T. M. Hyde, E. E. Burke, J. E. Kleiman, R. Tao, J. H. Shin, S. Akbarian, K. Girdhar, Y. Jiang, M. Kundakovic, L. Brown, B. S. Kassim, R. B. Park, J. R. Wiseman, E. Zharovsky, R. Jacobov, O. Devillers, E. Flatow, G. E. Hoffman, B. K. Lipska, D. A. Lewis, V. Haroutunian, C.-G. Hahn, A. W. Charney, S. Dracheva, A. Kozlenkov, J. Belmont, D. DelValle, N. Francoeur, E. Hadjimichael, D. Pinto, H. van Bakel, P. Roussos, J. F. Fullard, J. Bendl, M. E. Hauberg, L. M. Mangravite, M. A. Peters, Y. Chae, J. Peng, M. Niu, X. Wang, M. J. Webster, T. G. Beach, C. Chen, Y. Jiang, R. Dai, A. W. Shieh, C. Liu, K. S. Grennan, Y. Xia, R. Vadukapuram, Y. Wang, D. Fitzgerald, L. Cheng, M. Brown, M. Brown, T. Brunetti, T. Goodman, M. Alsayed, M. J. Gandal, D. H. Geschwind, H. Won, D. Polioudakis, B. Wamsley, J. Yin, T. Hadzic, L. D. L. T. Ubieta, V. Swarup, S. J. Sanders, M. W. State, D. M. Werling, J.-Y. An, B. Sheppard, A. J. Willsey, K. P. White, M. Ray, G. Giase, A. Kefi, E. Mattei, M. Purcaro, Z. Weng, J. Moore, H. Pratt, J. Huey, T. Borrman, P. F. Sullivan, P. Giusti-Rodriguez, Y. Kim, P. Sullivan, J. Szatkiewicz, S. K. Rhie, C. Armoskus, A. Camarena, P. J. Farnham, V. N. Spitsyna, H. Witt, S. Schreiner, O. V. Evgrafov, J. A. Knowles, M. Gerstein, S. Liu, D. Wang, F. C. P. Navarro, J. Warrell, D. Clarke, P. S. Emani, M. Gu, X. Shi, M. Xu, Y. T. Yang, R. R. Kitchen, G. Gürsoy, J. Zhang, B. C. Carlyle, A. C. Nairn, M. Li, S. Pochareddy, N. Sestan, M. Skarica, Z. Li, A. M. M. Sousa, G. Santpere, J. Choi, Y. Zhu, T. Gao, D. J. Miller, A. Cherskov, M. Yang, A. Amiri, G. Coppola, J. Mariani, S. Scuderi, A. Szekely, F. M. Vaccarino, F. Wu, S. Weissman, T. Roychowdhury, A. Abyzov, Comprehensive functional genomic resource and integrative model for the human brain. Science. 362, eaat8464 (2018).

55. R. McGill, J. W. Tukey, W. A. Larsen, Variations of Box Plots. Am Statistician. 32, 12 (1978).

56. N. Y. A. Sey, B. Hu, M. Iskhakova, H. Sun, N. Shokrian, G. B. Hutta, J. Marks, B. C. Quach, E. O. Johnson, D. B. Hancock, S. Akbarian, H. Won, Biorxiv, in press, doi:10.1101/2021.03.18.436046.

57. I. Jung, A. Schmitt, Y. Diao, A. J. Lee, T. Liu, D. Yang, C. Tan, J. Eom, M. Chan, S. Chee, Z. Chiang, C. Kim, E. Masliah, C. L. Barr, B. Li, S. Kuan, D. Kim, B. Ren, A compendium of promoter-centered long-range chromatin interactions in the human genome. Nat Genet. 51, 1442-1449 (2019).

40 58. M. Song, X. Yang, X. Ren, L. Maliskova, B. Li, I. R. Jones, C. Wang, F. Jacob, K. Wu, M. Traglia, T. W. Tam, K. Jamieson, S.-Y. Lu, G.-L. Ming, Y. Li, J. Yao, L. A. Weiss, J. R. Dixon, L. M. Judge, B. R. Conklin, H. Song, L. Gan, Y. Shen, Mapping cis-regulatory chromatin 
contacts in neural cells links neuropsychiatric disorder risk variants to target genes. Nat Genet. $51,1252-1262$ (2019).

59. C. Su, M. Argenziano, S. Lu, J. A. Pippin, M. C. Pahl, M. E. Leonard, D. L. Cousminer, M. E. Johnson, C. Lasconi, A. D. Wells, A. Chesi, S. F. A. Grant, 3D promoter architecture reorganization during iPSC-derived neuronal cell differentiation implicates target genes for neurodevelopmental disorders. Prog Neurobiol. 201, 102000 (2021).

60. L. Lu, X. Liu, W.-K. Huang, P. Giusti-Rodríguez, J. Cui, S. Zhang, W. Xu, Z. Wen, S. Ma, J. D. Rosen, Z. Xu, C. F. Bartels, R. Kawaguchi, M. Hu, P. C. Scacheri, Z. Rong, Y. Li, P. F. Sullivan, H. Song, G.-L. Ming, Y. Li, F. Jin, Robust Hi-C Maps of Enhancer-Promoter Interactions Reveal the Function of Non-coding Genome in Neural Development and Diseases. Mol Cell (2020), doi:10.1016/j.molcel.2020.06.007.

61. B. Hu, H. Won, W. Mah, R. B. Park, B. Kassim, K. Spiess, A. Kozlenkov, C. A. Crowley, S. Pochareddy, T. P. Consortium, A. E. Ashley-Koch, G. E. Crawford, M. E. Garrett, L. Song, A. Safi, G. D. Johnson, G. A. Wray, T. E. Reddy, F. S. Goes, P. Zandi, J. Bryois, A. E. Jaffe, A. J. Price, N. A. Ivanov, L. Collado-Torres, T. M. Hyde, E. E. Burke, J. E. Kleiman, R. Tao, J. H. Shin, K. Girdhar, Y. Jiang, M. Kundakovic, L. Brown, J. R. Wiseman, E. Zharovsky, R. Jacobov, O. Devillers, E. Flatow, G. E. Hoffman, J. Belmont, D. D. Valle, N. Francoeur, E. Hadjimichael, D. Pinto, H. van Bakel, P. Roussos, J. F. Fullard, J. Bendl, M. E. Hauberg, A. W. Charney, V. Haroutunian, B. K. Lipska, D. A. Lewis, C.-G. Hahn, L. M. Mangravite, M. A. Peters, Y. Chae, J. Peng, M. Niu, X. Wang, M. J. Webster, T. G. Beach, C. Chen, Y. Jiang, R. Dai, Y. Wang, Y. Xia, A. W. Shieh, C. Liu, K. S. Grennan, R. Vadukapuram, G. Giase, D. Fitzgerald, L. Cheng, M. Brown, M. Brown, T. Brunetti, T. Goodman, M. Alsayed, K. P. White, M. Ray, D. Polioudakis, B. Wamsley, J. Yin, L. D. L. T. Ubieta, M. J. Gandal, V. Swarup, S. J. Sanders, M. W. State, D. M. Werling, J.-Y. An, B. Sheppard, A. J. Willsey, A. Kefi, E. Mattei, M. Purcaro, Z. Weng, J. Moore, H. Pratt, J. Huey, T. Borrman, P. F. Sullivan, P. GiustiRodriguez, Y. Kim, J. Szatkiewicz, S. K. Rhie, C. Armoskus, A. Camarena, P. J. Farnham, V. N. Spitsyna, H. Witt, S. Schreiner, O. V. Evgrafov, J. A. Knowles, M. Gerstein, S. Liu, F. C. P. Navarro, J. Warrell, D. Clarke, P. S. Emani, M. Gu, X. Shi, M. Xu, Y. T. Yang, R. R. Kitchen, G. Gürsoy, J. Zhang, B. C. Carlyle, A. C. Nairn, M. Li, M. Skarica, Z. Li, A. M. M. Sousa, G. Santpere, J. Choi, Y. Zhu, T. Gao, D. J. Miller, A. Cherskov, M. Yang, A. Amiri, G. Coppola, J. Mariani, S. Scuderi, A. Szekely, F. M. Vaccarino, F. Wu, S. Weissman, D. Wang, T. Roychowdhury, A. Abyzov, Y. Li, S. Dracheva, N. Sestan, S. Akbarian, D. H. Geschwind, Neuronal and glial 3D chromatin architecture informs the cellular etiology of brain disorders. Nat Commun. 12, 3968 (2021).

62. E. Bernabeu, O. Canela-Xandri, K. Rawlik, A. Talenti, J. Prendergast, A. Tenesa, Sex differences in genetic architecture in the UK Biobank. Nat Genet. 53, 1283-1289 (2021).

63. B. Mulvey, D. L. Bhatti, S. Gyawali, A. M. Lake, S. Kriaucionis, C. P. Ford, M. R. Bruchas, N. Heintz, J. D. Dougherty, Molecular and Functional Sex Differences of Noradrenergic Neurons in the Mouse Locus Coeruleus. Cell Reports. 23, 2225-2235 (2018). 
64. S. G. Coetzee, G. A. Coetzee, D. J. Hazelett, motifbreakR: an R/Bioconductor package for predicting variant effects at transcription factor binding sites. Bioinform Oxf Engl. 31, 3847-9 (2015).

65. W. Santana-Garcia, M. Rocha-Acevedo, L. Ramirez-Navarro, Y. Mbouamboua, D. Thieffry, M. Thomas-Chollier, B. Contreras-Moreira, J. van Helden, A. Medina-Rivera, RSAT variationtools: An accessible and flexible framework to predict the impact of regulatory variants on transcription factor binding. Comput Struct Biotechnology J. 17, 1415-1428 (2019).

66. C. Chen, Q. Meng, Y. Xia, C. Ding, L. Wang, R. Dai, L. Cheng, P. Gunaratne, R. A. Gibbs, S. Min, C. Coarfa, J. G. Reid, C. Zhang, C. Jiao, Y. Jiang, G. Giase, A. Thomas, D. Fitzgerald, T. Brunetti, A. Shieh, C. Xia, Y. Wang, Y. Wang, J. A. Badner, E. S. Gershon, K. P. White, C. Liu, The transcription factor POU3F2 regulates a gene coexpression network in brain tissue from patients with psychiatric disorders. Sci Transl Med. 10, eaat8178 (2018).

67. Z. Xie, A. Bailey, M. V. Kuleshov, D. J. B. Clarke, J. E. Evangelista, S. L. Jenkins, A. Lachmann, M. L. Wojciechowicz, E. Kropiwnicki, K. M. Jagodnik, M. Jeon, A. Ma'ayan, Gene Set Knowledge Discovery with Enrichr. Curr Protoc. 1, e90 (2021).

68. M. Sharma, X. Li, Y. Wang, M. Zarnegar, C. Huang, J. J. Palvimo, B. Lim, Z. Sun, hZimp10 is an androgen receptor co-activator and forms a complex with SUMO-1 at replication foci. Embo J. 22, 6101-6114 (2003).

69. X. Li, G. Thyssen, J. Beliakoff, Z. Sun, The Novel PIAS-like Protein hZimp10 Enhances Smad Transcriptional Activity. J Biol Chem. 281, 23748-23756 (2006).

70. E. S. Williams, M. Mazei-Robison, A. J. Robison, Sex Differences in Major Depressive Disorder (MDD) and Preclinical Animal Models for the Study of Depression. Csh Perspect Biol, a039198 (2021).

71. A. Kawatake-Kuno, T. Murai, S. Uchida, The Molecular Basis of Depression: Implications of Sex-Related Differences in Epigenetic Regulation. Front Mol Neurosci. 14, 708004 (2021).

72. H. Won, L. de la Torre-Ubieta, J. L. Stein, N. N. Parikshak, J. Huang, C. K. Opland, M. J. Gandal, G. J. Sutton, F. Hormozdiari, D. Lu, C. Lee, E. Eskin, I. Voineagu, J. Ernst, D. H. Geschwind, Chromosome conformation elucidates regulatory relationships in developing human brain. Nature. 538, 523-527 (2016).

30 73. P. Chakrabarty, A. Rosario, P. Cruz, Z. Siemienski, C. Ceballos-Diaz, K. Crosby, K. Jansen, D. R. Borchelt, J.-Y. Kim, J. L. Jankowsky, T. E. Golde, Y. Levites, Capsid Serotype and Timing of Injection Determines AAV Transduction in the Neonatal Mice Brain. Plos One. 8, e67680 (2013).

74. C. L. Thompson, L. Ng, V. Menon, S. Martinez, C.-K. Lee, K. Glattfelder, S. M. Sunkin, A. Henry, C. Lau, C. Dang, R. Garcia-Lopez, A. Martinez-Ferre, A. Pombero, J. L. R. Rubenstein, W. B. Wakeman, J. Hohmann, N. Dee, A. J. Sodt, R. Young, K. Smith, T.-N. Nguyen, J. Kidney, L. Kuan, A. Jeromin, A. Kaykas, J. Miller, D. Page, G. Orta, A. Bernard, Z. Riley, S. Smith, P. 
Wohnoutka, M. J. Hawrylycz, L. Puelles, A. R. Jones, A High-Resolution Spatiotemporal Atlas of Gene Expression of the Developing Mouse Brain. Neuron. 83, 309-323 (2014).

75. S. Li, Y. Li, X. Li, J. Liu, Y. Huo, J. Wang, Z. Liu, M. Li, X.-J. Luo, Regulatory mechanisms of major depressive disorder risk variants. Mol Psychiatr, 1-20 (2020).

76. D. Liang, A. L. Elwell, N. Aygün, O. Krupa, J. M. Wolter, F. A. Kyere, M. J. Lafferty, K. E. Cheek, K. P. Courtney, M. Yusupova, M. E. Garrett, A. Ashley-Koch, G. E. Crawford, M. I. Love, L. de la Torre-Ubieta, D. H. Geschwind, J. L. Stein, Cell-type-specific effects of genetic variation on chromatin accessibility during human neuronal differentiation. Nat Neurosci. 24, 941-953 (2021).

77. N. Aragam, K.-S. Wang, Y. Pan, Genome-wide association analysis of gender differences in major depressive disorder in the Netherlands NESDA and NTR population-based samples. $J$ Affect Disorders. 133, 516-521 (2011).

78. J. Cui, Y. Yang, C. Zhang, P. Hu, W. Kan, X. Bai, X. Liu, H. Song, FBI-1 functions as a novel AR co-repressor in prostate cancer cells. Cell Mol Life Sci. 68, 1091-1103 (2011).

79. L. Zhang, Y. Wang, X. Li, X. Xia, N. Li, R. He, H. He, C. Han, W. Zhao, ZBTB7A Enhances Osteosarcoma Chemoresistance by Transcriptionally Repressing IncRNA LINC00473IL24 Activity. Neoplasia New York N Y. 19, 908-918 (2017).

80. O. Issler, Y. Y. van der Zee, A. Ramakrishnan, J. Wang, C. Tan, Y.-H. E. Loh, I. Purushothaman, D. M. Walker, Z. S. Lorsch, P. J. Hamilton, C. J. Peña, E. Flaherty, B. J.

20 Hartley, A. Torres-Berrío, E. M. Parise, H. Kronman, J. E. Duffy, M. S. Estill, E. S. Calipari, B. Labonté, R. L. Neve, C. A. Tamminga, K. J. Brennand, Y. Dong, L. Shen, E. J. Nestler, SexSpecific Role for the Long Non-coding RNA LINC00473 in Depression. Neuron (2020), doi:10.1016/j.neuron.2020.03.023.

81. L. Dion-Albert, A. Cadoret, E. Doney, F. N. Kaufmann, K. A. Dudek, L. F. Parise, F. Cathomas, N. Samba, N. Hudson, M. Lebel, S. Consortium, M. Campbell, G. Turecki, N. Mechawar, C. Menard, Biorxiv, in press, doi:10.1101/2021.04.23.441142.

82. J. C. Klein, V. Agarwal, F. Inoue, A. Keith, B. Martin, M. Kircher, N. Ahituv, J. Shendure, A systematic evaluation of the design and context dependencies of massively parallel reporter assays. Nat Methods, 1-9 (2020). testing of ENCODE segmentation predictions. Genome Res. 24, 1595-1602 (2014).

84. M. Li, N. Husic, Y. Lin, H. Christensen, I. Malik, S. McIver, C. M. L. Daniels, D. A. Harris, P. T. Kotzbauer, M. P. Goldberg, B. J. Snider, Optimal promoter usage for lentiviral vectormediated transduction of cultured central nervous system cells. J Neurosci Meth. 189, 56-64 (2010). 
85. Y. Lee, A. Messing, M. Su, M. Brenner, GFAP promoter elements required for regionspecific and astrocyte-specific expression. Glia. 56, 481-493 (2008).

86. K. Sakers, A. M. Lake, R. Khazanchi, R. Ouwenga, M. J. Vasek, A. Dani, J. D. Dougherty, Astrocytes locally translate transcripts in their peripheral processes. Proc National Acad Sci. 114, E3830-E3838 (2017).

87. J. P. Doyle, J. D. Dougherty, M. Heiman, E. F. Schmidt, T. R. Stevens, G. Ma, S. Bupp, P. Shrestha, R. D. Shah, M. L. Doughty, S. Gong, P. Greengard, N. Heintz, Application of a translational profiling approach for the comparative analysis of CNS cell types. Cell. 135, 74962 (2008).

88. D. Demontis, R. K. Walters, J. Martin, M. Mattheisen, T. D. Als, E. Agerbo, G. Baldursson, R. Belliveau, J. Bybjerg-Grauholm, M. Bækvad-Hansen, F. Cerrato, K. Chambert, C. Churchhouse, A. Dumont, N. Eriksson, M. Gandal, J. I. Goldstein, K. L. Grasby, J. Grove, O. O. Gudmundsson, C. S. Hansen, M. E. Hauberg, M. V. Hollegaard, D. P. Howrigan, H. Huang, J. B. Maller, A. R. Martin, N. G. Martin, J. Moran, J. Pallesen, D. S. Palmer, C. B. Pedersen, M. G. Pedersen, T. Poterba, J. B. Poulsen, S. Ripke, E. B. Robinson, F. K. Satterstrom, H. Stefansson, C. Stevens, P. Turley, G. B. Walters, H. Won, M. J. Wright, Ö. Albayrak, R. J. L. Anney, M. J. Arranz, T. J. Banaschewski, C. Bau, J. Biederman, J. K. Buitelaar, M. Casas, A. Charach, J. Crosbie, A. Dempfle, A. E. Doyle, R. P. Ebstein, J. Elia, C. Freitag, M. Föcker, M. Gill, E. Grevet, Z. Hawi, J. Hebebrand, B. Herpertz-Dahlmann, A. Hervas, A. Hinney, S. Hohmann, P. Holmans, M. Hutz, A. Ickowitz, S. Johansson, L. Kent, S. Kittel-Schneider, N. LambregtsRommelse, G. Lehmkuhl, S. K. Loo, J. J. McGough, J. Meyer, E. Mick, F. Middletion, A. Miranda, N. R. Mota, F. Mulas, A. Mulligan, F. Nelson, T. T. Nguyen, R. D. Oades, M. C. O’Donovan, M. J. Owen, H. Palmason, J. A. Ramos-Quiroga, T. J. Renner, M. Ribasés, M. Rietschel, O. Rivero, J. Romanos, M. Romanos, A. Rothenberger, H. Royers, C. Sánchez-Mora, A. Scherag, B. G. Schimmelmann, H. Schäfer, J. Sergeant, J. Sinzig, S. L. Smalley, H.-C. Steinhausen, M. Thompson, A. Todorov, A. A. Vasquez, S. Walitza, Y. Wang, A. Warnke, N. Williams, S. H. Witt, L. Yang, T. Zayats, Y. Zhang-James, G. D. Smith, G. E. Davies, E. A. Ehli, D. M. Evans, I. O. Fedko, C. U. Greven, M. M. Groen-Blokhuis, M. Guxens, A. R. Hammerschlag, C. A. Hartman, J. Heinrich, J. J. Hottenga, J. Hudziak, A. Jugessur, J. P. Kemp, E. Krapohl, M. Murcia, R. Myhre, I. M. Nolte, D. R. Nyholt, J. Ormel, K. G. Ouwens, I. Pappa, C. E. Pennell, R. Plomin, S. Ring, M. Standl, E. Stergiakouli, B. S. Pourcain, C. Stoltenberg, J. Sunyer, E. Thiering, H. Tiemeier, C. M. T. Tiesler, N. J. Timpson, M. Trzaskowski, P. J. van der Most, N. Vilor-Tejedor, C. A. Wang, A. J. O. Whitehouse, H. Zhao, M. Agee, B. Alipanahi, A. Auton, R. K. Bell, K. Bryc, S. L. Elson, P. Fontanillas, N. A. Furlotte, D. A. Hinds, B. S. Hromatka, K. E. Huber, A. Kleinman, N. K. Litterman, M. H. McIntyre, J. L. Mountain, C. A. M. Northover, S. J. Pitts, J. F. Sathirapongsasuti, O. V. Sazonova, J. F. Shelton, S. Shringarpure, C. Tian, V. Vacic, C. H. Wilson, O. A. Andreassen, P. Asherson, C. L. Burton, D. I. Boomsma, B. Cormand, S. Dalsgaard, B. Franke, J. Gelernter, D. Geschwind, H. Hakonarson, J. Haavik, H. R. Kranzler, J. Kuntsi, K. Langley, K.-P. Lesch, C. Middeldorp, A. Reif, L. A. Rohde, P. Roussos, R. Schachar, P. Sklar, E. J. S. Sonuga-Barke, P. F. Sullivan, A. Thapar, J. Y. Tung, I. D. Waldman, S. E. Medland, K. Stefansson, M. Nordentoft, D. M. Hougaard, T. Werge, O. Mors, P. B. Mortensen, M. J. Daly, S. V. Faraone, A. D. Børglum, B. M. Neale, Discovery of the first genome-wide significant risk loci for attention deficit/hyperactivity disorder. Nat Genet. 51, 63-75 (2018). 
89. W. D. Hill, R. E. Marioni, O. Maghzian, S. J. Ritchie, S. P. Hagenaars, A. M. McIntosh, C. R. Gale, G. Davies, I. J. Deary, A combined analysis of genetically correlated traits identifies 187 loci and a role for neurogenesis and myelination in intelligence. Mol Psychiatr. 24, 169-181 (2018).

90. J. J. Lee, R. Wedow, A. Okbay, E. Kong, O. Maghzian, M. Zacher, T. A. Nguyen-Viet, P. Bowers, J. Sidorenko, R. K. Linnér, M. A. Fontana, T. Kundu, C. Lee, H. Li, R. Li, R. Royer, P. N. Timshel, R. K. Walters, E. A. Willoughby, L. Yengo, 23andMe Research Team, C. (Cognitive G. Consortium), S. S. G. A. Consortium, M. Alver, Y. Bao, D. W. Clark, F. R. Day, N. A. Furlotte, P. K. Joshi, K. E. Kemper, A. Kleinman, C. Langenberg, R. Mägi, J. W.

Trampush, S. S. Verma, Y. Wu, M. Lam, J. H. Zhao, Z. Zheng, J. D. Boardman, H. Campbell, J. Freese, K. M. Harris, C. Hayward, P. Herd, M. Kumari, T. Lencz, J. Luan, A. K. Malhotra, A. Metspalu, L. Milani, K. K. Ong, J. R. B. Perry, D. J. Porteous, M. D. Ritchie, M. C. Smart, B. H. Smith, J. Y. Tung, N. J. Wareham, J. F. Wilson, J. P. Beauchamp, D. C. Conley, T. Esko, S. F. Lehrer, P. K. E. Magnusson, S. Oskarsson, T. H. Pers, M. R. Robinson, K. Thom, C. Watson, C. F. Chabris, M. N. Meyer, D. I. Laibson, J. Yang, M. Johannesson, P. D. Koellinger, P. Turley, P. M. Visscher, D. J. Benjamin, D. Cesarini, Gene discovery and polygenic prediction from a genome-wide association study of educational attainment in 1.1 million individuals. Nat Genet. 50, 1112-1121 (2018).

91. M. Ghoussaini, E. Mountjoy, M. Carmona, G. Peat, E. M. Schmidt, A. Hercules, L. Fumis, A. Miranda, D. Carvalho-Silva, A. Buniello, T. Burdett, J. Hayhurst, J. Baker, J. Ferrer, A. Gonzalez-Uriarte, S. Jupp, M. A. Karim, G. Koscielny, S. Machlitt-Northen, C. Malangone, Z. M. Pendlington, P. Roncaglia, D. Suveges, D. Wright, O. Vrousgou, E. Papa, H. Parkinson, J. A. L. MacArthur, J. A. Todd, J. C. Barrett, J. Schwartzentruber, D. G. Hulcoop, D. Ochoa, E. M. McDonagh, I. Dunham, Open Targets Genetics: systematic identification of trait-associated genes using large-scale genetics and functional genomics. Nucleic Acids Res. 49, gkaa840(2020).

92. M. J. Machiela, S. J. Chanock, LDlink: a web-based application for exploring populationspecific haplotype structure and linking correlated alleles of possible functional variants.

Bioinformatics. 31, 3555-3557 (2015).

93. F. Aguet, A. A. Brown, S. E. Castel, J. R. Davis, Y. He, B. Jo, P. Mohammadi, Y. Park, P. Parsana, A. V. Segrè, B. J. Strober, Z. Zappala, B. B. Cummings, E. T. Gelfand, K. Hadley, K. H. Huang, M. Lek, X. Li, J. L. Nedzel, D. Y. Nguyen, M. S. Noble, T. J. Sullivan, T. Tukiainen, D. G. MacArthur, G. Getz, A. Addington, P. Guan, S. Koester, A. R. Little, N. C. Lockhart, H. M. Moore, A. Rao, J. P. Struewing, S. Volpi, L. E. Brigham, R. Hasz, M. Hunter, C. Johns, M. Johnson, G. Kopen, W. F. Leinweber, J. T. Lonsdale, A. McDonald, B. Mestichelli, K. Myer, B. Roe, M. Salvatore, S. Shad, J. A. Thomas, G. Walters, M. Washington, J. Wheeler, J. Bridge, B. A. Foster, B. M. Gillard, E. Karasik, R. Kumar, M. Miklos, M. T. Moser, S. D. Jewell, R. G. Montroy, D. C. Rohrer, D. Valley, D. C. Mash, D. A. Davis, L. Sobin, M. E. Barcus, P. A. Branton, N. S. Abell, B. Balliu, O. Delaneau, L. Frésard, E. R. Gamazon, D. Garrido-Martín, A. D. H. Gewirtz, G. Gliner, M. J. Gloudemans, B. Han, A. Z. He, F. Hormozdiari, X. Li, B. Liu, E. Y. Kang, I. C. McDowell, H. Ongen, J. J. Palowitch, C. B. Peterson, G. Quon, S. Ripke, A. Saha, A. A. Shabalin, T. C. Shimko, J. H. Sul, N. A. Teran, E. K. Tsang, H. Zhang, Y.-H. Zhou, C. D. Bustamante, N. J. Cox, R. Guigó, M. Kellis, M. I. McCarthy, D. F. Conrad, E. Eskin, G. Li, A. 
B. Nobel, C. Sabatti, B. E. Stranger, X. Wen, F. A. Wright, K. G. Ardlie, E. T. Dermitzakis, T. Lappalainen, F. Aguet, K. G. Ardlie, B. B. Cummings, E. T. Gelfand, G. Getz, K. Hadley, R. E. Handsaker, K. H. Huang, S. Kashin, K. J. Karczewski, M. Lek, X. Li, D. G. MacArthur, J. L. Nedzel, D. T. Nguyen, M. S. Noble, A. V. Segrè, C. A. Trowbridge, T. Tukiainen, N. S. Abell, B. Balliu, R. Barshir, O. Basha, A. Battle, G. K. Bogu, A. Brown, C. D. Brown, S. E. Castel, L. S. Chen, C. Chiang, D. F. Conrad, N. J. Cox, F. N. Damani, J. R. Davis, O. Delaneau, E. T. Dermitzakis, B. E. Engelhardt, E. Eskin, P. G. Ferreira, L. Frésard, E. R. Gamazon, D. GarridoMartín, A. D. H. Gewirtz, G. Gliner, M. J. Gloudemans, R. Guigo, I. M. Hall, B. Han, Y. He, F. Hormozdiari, C. Howald, H. K. Im, B. Jo, E. Y. Kang, Y. Kim, S. Kim-Hellmuth, T.

Lappalainen, G. Li, X. Li, B. Liu, S. Mangul, M. I. McCarthy, I. C. McDowell, P. Mohammadi, J. Monlong, S. B. Montgomery, M. Muñoz-Aguirre, A. W. Ndungu, D. L. Nicolae, A. B. Nobel, M. Oliva, H. Ongen, J. J. Palowitch, N. Panousis, P. Papasaikas, Y. Park, P. Parsana, A. J.

Payne, C. B. Peterson, J. Quan, F. Reverter, C. Sabatti, A. Saha, M. Sammeth, A. J. Scott, A. A. Shabalin, R. Sodaei, M. Stephens, B. E. Stranger, B. J. Strober, J. H. Sul, E. K. Tsang, S. Urbut, M. van de Bunt, G. Wang, X. Wen, F. A. Wright, H. S. Xi, E. Yeger-Lotem, Z. Zappala, J. B. Zaugg, Y.-H. Zhou, J. M. Akey, D. Bates, J. Chan, L. S. Chen, M. Claussnitzer, K. Demanelis, M. Diegel, J. A. Doherty, A. P. Feinberg, M. S. Fernando, J. Halow, K. D. Hansen, E. Haugen, P. F. Hickey, L. Hou, F. Jasmine, R. Jian, L. Jiang, A. Johnson, R. Kaul, M. Kellis, M. G.

Kibriya, K. Lee, J. B. Li, Q. Li, X. Li, J. Lin, S. Lin, S. Linder, C. Linke, Y. Liu, M. T. Maurano, B. Molinie, S. B. Montgomery, J. Nelson, F. J. Neri, M. Oliva, Y. Park, B. L. Pierce, N. J. Rinaldi, L. F. Rizzardi, R. Sandstrom, A. Skol, K. S. Smith, M. P. Snyder, J. Stamatoyannopoulos, B. E. Stranger, H. Tang, E. K. Tsang, L. Wang, M. Wang, N. V. Wittenberghe, F. Wu, R. Zhang, C. R. Nierras, P. A. Branton, L. J. Carithers, P. Guan, H. M. Moore, A. Rao, J. B. Vaught, S. E. Gould, N. C. Lockart, C. Martin, J. P. Struewing, S. Volpi, A. M. Addington, S. E. Koester, A. R. Little, L. E. Brigham, R. Hasz, M. Hunter, C. Johns, M. Johnson, G. Kopen, W. F. Leinweber, J. T. Lonsdale, A. McDonald, B. Mestichelli, K. Myer, B. Roe, M. Salvatore, S. Shad, J. A. Thomas, G. Walters, M. Washington, J. Wheeler, J. Bridge, B. A. Foster, B. M. Gillard, E. Karasik, R. Kumar, M. Miklos, M. T. Moser, S. D. Jewell, R. G. Montroy, D. C. Rohrer, D. R. Valley, D. A. Davis, D. C. Mash, A. H. Undale, A. M. Smith, D. E. Tabor, N. V. Roche, J. A. McLean, N. Vatanian, K. L. Robinson, L. Sobin, M. E. Barcus, K. M. Valentino, L. Qi, S. Hunter, P. Hariharan, S. Singh, K. S. Um, T. Matose, M. M. Tomaszewski, L. K. Barker, M. Mosavel, L. A. Siminoff, H. M. Traino, P. Flicek, T. Juettemann, M. Ruffier, D. Sheppard, K. Taylor, S. J. Trevanion, D. R. Zerbino, B. Craft, M. Goldman, M. Haeussler, W. J. Kent, C. M. Lee, B. Paten, K. R. Rosenbloom, J. Vivian, J. Zhu, Genetic effects on gene expression across human tissues. Nature. 550, 204-213 (2017).

94. M. E. Hauberg, W. Zhang, C. Giambartolomei, O. Franzén, D. L. Morris, T. J. Vyse, A. Ruusalepp, C. Consortium, M. Fromer, S. K. Sieberts, J. S. Johnson, D. M. Ruderfer, H. R. Shah, L. L. Klei, K. K. Dang, T. M. Perumal, B. A. Logsdon, M. C. Mahajan, L. M. Mangravite, L. Essioux, H. Toyoshiba, R. E. Gur, C.-G. Hahn, D. A. Lewis, V. Haroutunian, M. A. Peters, B. K. 40 Lipska, J. D. Buxbaum, K. Hirai, E. Domenici, B. Devlin, P. Sklar, E. E. Schadt, J. L. M. Björkegren, P. Roussos, Large-Scale Identification of Common Trait and Disease Variants Affecting Gene Expression. Am J Hum Genetics. 101, 157 (2017).

95. T. B. Consortium, A. E. Jaffe, R. E. Straub, J. H. Shin, R. Tao, Y. Gao, L. Collado-Torres, T. Kam-Thong, H. S. Xi, J. Quan, Q. Chen, C. Colantuoni, W. S. Ulrich, B. J. Maher, A. DeepSoboslay, A. J. Cross, N. J. Brandon, J. T. Leek, T. M. Hyde, J. E. Kleinman, D. R. Weinberger, 
Developmental and genetic regulation of the human cortex transcriptome illuminate schizophrenia pathogenesis. Nat Neurosci. 21, 1117-1125 (2018).

96. B. Ng, C. C. White, H.-U. Klein, S. K. Sieberts, C. McCabe, E. Patrick, J. Xu, L. Yu, C. Gaiteri, D. A. Bennett, S. Mostafavi, P. L. D. Jager, An xQTL map integrates the genetic architecture of the human brain's transcriptome and epigenome. Nat Neurosci. 20, 1418-1426 (2017).

97. R. Andersson, C. Gebhard, I. Miguel-Escalada, I. Hoof, J. Bornholdt, M. Boyd, Y. Chen, X. Zhao, C. Schmidl, T. Suzuki, E. Ntini, E. Arner, E. Valen, K. Li, L. Schwarzfischer, D. Glatz, J. Raithel, B. Lilje, N. Rapin, F. O. Bagger, M. Jørgensen, P. R. Andersen, N. Bertin, O. Rackham, A. M. Burroughs, J. K. Baillie, Y. Ishizu, Y. Shimizu, E. Furuhata, S. Maeda, Y. Negishi, C. J. Mungall, T. F. Meehan, T. Lassmann, M. Itoh, H. Kawaji, N. Kondo, J. Kawai, A. Lennartsson, C. O. Daub, P. Heutink, D. A. Hume, T. H. Jensen, H. Suzuki, Y. Hayashizaki, F. Müller, F. Consortium, A. R. R. Forrest, P. Carninci, M. Rehli, A. Sandelin, An atlas of active enhancers across human cell types and tissues. Nature. 507, 455-61 (2014).

98. F. C. and the R. P. and C. (DGT), A. R. R. Forrest, H. Kawaji, M. Rehli, J. K. Baillie, M. J. L. de Hoon, V. Haberle, T. Lassmann, I. V. Kulakovskiy, M. Lizio, M. Itoh, R. Andersson, C. J. Mungall, T. F. Meehan, S. Schmeier, N. Bertin, M. Jørgensen, E. Dimont, E. Arner, C. Schmidl, U. Schaefer, Y. A. Medvedeva, C. Plessy, M. Vitezic, J. Severin, C. A. Semple, Y. Ishizu, R. S. Young, M. Francescatto, I. Alam, D. Albanese, G. M. Altschuler, T. Arakawa, J. A. C. Archer, P. Arner, M. Babina, S. Rennie, P. J. Balwierz, A. G. Beckhouse, S. Pradhan-Bhatt, J. A. Blake, A. Blumenthal, B. Bodega, A. Bonetti, J. Briggs, F. Brombacher, A. M. Burroughs, A. Califano, C. V. Cannistraci, D. Carbajo, Y. Chen, M. Chierici, Y. Ciani, H. C. Clevers, E. Dalla, C. A. Davis, M. Detmar, A. D. Diehl, T. Dohi, F. Drabløs, A. S. B. Edge, M. Edinger, K. Ekwall, M. Endoh, H. Enomoto, M. Fagiolini, L. Fairbairn, H. Fang, M. C. Farach-Carson, G. J. Faulkner, A. V. Favorov, M. E. Fisher, M. C. Frith, R. Fujita, S. Fukuda, C. Furlanello, M. Furino, J. Furusawa, T. B. Geijtenbeek, A. P. Gibson, T. Gingeras, D. Goldowitz, J. Gough, S. Guhl, R. Guler, S. Gustincich, T. J. Ha, M. Hamaguchi, M. Hara, M. Harbers, J. Harshbarger, A.

Hasegawa, Y. Hasegawa, T. Hashimoto, M. Herlyn, K. J. Hitchens, S. J. H. Sui, O. M. Hofmann, I. Hoof, F. Hori, L. Huminiecki, K. Iida, T. Ikawa, B. R. Jankovic, H. Jia, A. Joshi, G. Jurman, B. Kaczkowski, C. Kai, K. Kaida, A. Kaiho, K. Kajiyama, M. Kanamori-Katayama, A. S. Kasianov, T. Kasukawa, S. Katayama, S. Kato, S. Kawaguchi, H. Kawamoto, Y. I. Kawamura, T. Kawashima, J. S. Kempfle, T. J. Kenna, J. Kere, L. M. Khachigian, T. Kitamura, S. P. Klinken, A. J. Knox, M. Kojima, S. Kojima, N. Kondo, H. Koseki, S. Koyasu, S. Krampitz, A. Kubosaki, A. T. Kwon, J. F. J. Laros, W. Lee, A. Lennartsson, K. Li, B. Lilje, L. Lipovich, A. Mackay-Sim, R. Manabe, J. C. Mar, B. Marchand, A. Mathelier, N. Mejhert, A. Meynert, Y. Mizuno, D. A. de L. Morais, H. Morikawa, M. Morimoto, K. Moro, E. Motakis, H. Motohashi, C. L. Mummery, M. Murata, S. Nagao-Sato, Y. Nakachi, F. Nakahara, T. Nakamura, Y. Nakamura, K. Nakazato, E. van Nimwegen, N. Ninomiya, H. Nishiyori, S. Noma, S. Noma, T. Noazaki, S. Ogishima, N. Ohkura, H. Ohimiya, H. Ohno, M. Ohshima, M. Okada-Hatakeyama, Y. Okazaki, V. Orlando, D. A. Ovchinnikov, A. Pain, R. Passier, M. Patrikakis, H. Persson, S. Piazza, J. G. D. Prendergast, O. J. L. Rackham, J. A. Ramilowski, M. Rashid, T. Ravasi, P. Rizzu, M. Roncador, S. Roy, M. B. Rye, E. Saijyo, A. Sajantila, A. Saka, S. Sakaguchi, M. Sakai, H. Sato, S. Savvi, A. Saxena, C. Schneider, E. A. Schultes, G. G. Schulze-Tanzil, A. Schwegmann, T. Sengstag, G. Sheng, H. Shimoji, Y. Shimoni, J. W. Shin, C. Simon, D. 
Sugiyama, T. Sugiyama, M. Suzuki, N. Suzuki, R. K. Swoboda, P. A. C. ’t Hoen, M. Tagami, N. Takahashi, J. Takai, H. Tanaka, H. Tatsukawa, Z. Tatum, M. Thompson, H. Toyodo, T. Toyoda, E. Valen, M. van de Wetering, L. M. van den Berg, R. Verado, D. Vijayan, I. E. Vorontsov, W. W. Wasserman, S. Watanabe, C. A. Wells, L. N. Winteringham, E. Wolvetang, E. J. Wood, Y. Yamaguchi, M. Yamamoto, M. Yoneda, Y. Yonekura, S. Yoshida, S. E. Zabierowski, P. G. Zhang, X. Zhao, S. Zucchelli, K. M. Summers, H. Suzuki, C. O. Daub, J. Kawai, P. Heutink, W. Hide, T. C. Freeman, B. Lenhard, V. B. Bajic, M. S. Taylor, V. J. Makeev, A. Sandelin, D. A. Hume, P. Carninci, Y. Hayashizaki, A promoter-level mammalian expression atlas. Nature. 507, 462-70 (2014).

99. I. Dunham, A. Kundaje, S. F. Aldred, P. J. Collins, C. A. Davis, F. Doyle, C. B. Epstein, S. Frietze, J. Harrow, R. Kaul, J. Khatun, B. R. Lajoie, S. G. Landt, B.-K. Lee, F. Pauli, K. R. Rosenbloom, P. Sabo, A. Safi, A. Sanyal, N. Shoresh, J. M. Simon, L. Song, N. D. Trinklein, R. C. Altshuler, E. Birney, J. B. Brown, C. Cheng, S. Djebali, X. Dong, I. Dunham, J. Ernst, T. S. Furey, M. Gerstein, B. Giardine, M. Greven, R. C. Hardison, R. S. Harris, J. Herrero, M. M. Hoffman, S. Iyer, M. Kellis, J. Khatun, P. Kheradpour, A. Kundaje, T. Lassmann, Q. Li, X. Lin, G. K. Marinov, A. Merkel, A. Mortazavi, S. C. J. Parker, T. E. Reddy, J. Rozowsky, F. Schlesinger, R. E. Thurman, J. Wang, L. D. Ward, T. W. Whitfield, S. P. Wilder, W. Wu, H. S. Xi, K. Y. Yip, J. Zhuang, B. E. Bernstein, E. Birney, I. Dunham, E. D. Green, C. Gunter, M. Snyder, M. J. Pazin, R. F. Lowdon, L. A. L. Dillon, L. B. Adams, C. J. Kelly, J. Zhang, J. R. Wexler, E. D. Green, P. J. Good, E. A. Feingold, B. E. Bernstein, E. Birney, G. E. Crawford, J. Dekker, L. Elnitski, P. J. Farnham, M. Gerstein, M. C. Giddings, T. R. Gingeras, E. D. Green, R. Guigó, R. C. Hardison, T. J. Hubbard, M. Kellis, W. J. Kent, J. D. Lieb, E. H. Margulies, R. M. Myers, M. Snyder, J. A. Stamatoyannopoulos, S. A. Tenenbaum, Z. Weng, K. P. White, B. Wold, J. Khatun, Y. Yu, J. Wrobel, B. A. Risk, H. P. Gunawardena, H. C. Kuiper, C. W. Maier, L. Xie, X. Chen, M. C. Giddings, B. E. Bernstein, C. B. Epstein, N. Shoresh, J. Ernst, P. Kheradpour, T. S. Mikkelsen, S. Gillespie, A. Goren, O. Ram, X. Zhang, L. Wang, R. Issner, M. J. Coyne, T. Durham, M. Ku, T. Truong, L. D. Ward, R. C. Altshuler, M. L. Eaton, M. Kellis, S. Djebali, C. A. Davis, A. Merkel, A. Dobin, T. Lassmann, A. Mortazavi, A. Tanzer, J. Lagarde, W. Lin, F. Schlesinger, C. Xue, G. K. Marinov, J. Khatun, B. A. Williams, C. Zaleski, J. Rozowsky, M. Röder, F. Kokocinski, R. F. Abdelhamid, T. Alioto, I. Antoshechkin, M. T. Baer, P. Batut, I. Bell, K. Bell, S. Chakrabortty, X. Chen, J. Chrast, J. Curado, T. Derrien, J. Drenkow, E. Dumais, J. Dumais, R. Duttagupta, M. Fastuca, K. Fejes-Toth, P. Ferreira, S. Foissac, M. J. Fullwood, H. Gao, D. Gonzalez, A. Gordon, H. P. Gunawardena, C. Howald, S. Jha, R. Johnson, P. Kapranov, B. King, C. Kingswood, G. Li, O. J. Luo, E. Park, J. B. Preall, K. Presaud, P. Ribeca, B. A. Risk, D. Robyr, X. Ruan, M. Sammeth, K. S. Sandhu, L. Schaeffer, L.-H. See, A. Shahab, J. Skancke, A. M. Suzuki, H. Takahashi, H. Tilgner, D. Trout, N. Walters, H. Wang, J. Wrobel, Y. Yu, Y. Hayashizaki, J. Harrow, M. Gerstein, T. J. Hubbard, A. Reymond, S. E. Antonarakis, G. J. Hannon, M. C. Giddings, Y. Ruan, B. Wold, P. Carninci, R. Guigó, T. R. Gingeras, K. R. Rosenbloom, C. A. Sloan, K. Learned, V. S. Malladi, M. C. Wong, G. P. Barber, 40 M. S. Cline, T. R. Dreszer, S. G. Heitner, D. Karolchik, W. J. Kent, V. M. Kirkup, L. R. Meyer, J. C. Long, M. Maddren, B. J. Raney, T. S. Furey, L. Song, L. L. Grasfeder, P. G. Giresi, B.-K. Lee, A. Battenhouse, N. C. Sheffield, J. M. Simon, K. A. Showers, A. Safi, D. London, A. A. Bhinge, C. Shestak, M. R. Schaner, S. K. Kim, Z. Z. Zhang, P. A. Mieczkowski, J. O. Mieczkowska, Z. Liu, R. M. McDaniell, Y. Ni, N. U. Rashid, M. J. Kim, S. Adar, Z. Zhang, T. 45 Wang, D. Winter, D. Keefe, E. Birney, V. R. Iyer, J. D. Lieb, G. E. Crawford, G. Li, K. S. Sandhu, M. Zheng, P. Wang, O. J. Luo, A. Shahab, M. J. Fullwood, X. Ruan, Y. Ruan, R. M. 
Myers, F. Pauli, B. A. Williams, J. Gertz, G. K. Marinov, T. E. Reddy, J. Vielmetter, E. Partridge, D. Trout, K. E. Varley, C. Gasper, A. Bansal, S. Pepke, P. Jain, H. Amrhein, K. M. Bowling, M. Anaya, M. K. Cross, B. King, M. A. Muratet, I. Antoshechkin, K. M. Newberry, K. McCue, A. S. Nesmith, K. I. Fisher-Aylor, B. Pusey, G. DeSalvo, S. L. Parker, S. Balasubramanian, N. S. Davis, S. K. Meadows, T. Eggleston, C. Gunter, J. S. Newberry, S. E. Levy, D. M. Absher, A. Mortazavi, W. H. Wong, B. Wold, M. J. Blow, A. Visel, L. A. Pennachio, L. Elnitski, E. H. Margulies, S. C. J. Parker, H. M. Petrykowska, A. Abyzov, B. Aken, D. Barrell, G. Barson, A. Berry, A. Bignell, V. Boychenko, G. Bussotti, J. Chrast, C. Davidson, T. Derrien, G. Despacio-Reyes, M. Diekhans, I. Ezkurdia, A. Frankish, J. Gilbert, J. M. Gonzalez, E. Griffiths, R. Harte, D. A. Hendrix, C. Howald, T. Hunt, I. Jungreis, M. Kay, E. Khurana, F. Kokocinski, J. Leng, M. F. Lin, J. Loveland, Z. Lu, D. Manthravadi, M. Mariotti, J. Mudge, G. Mukherjee, C. Notredame, B. Pei, J. M. Rodriguez, G. Saunders, A. Sboner, S. Searle, C. Sisu, C. Snow, C. Steward, A. Tanzer, E. Tapanari, M. L. Tress, M. J. van Baren, N. Walters, S. Washietl, L. Wilming, A. Zadissa, Z. Zhang, M. Brent, D. Haussler, M. Kellis, A. Valencia, M. Gerstein, A. Reymond, R. Guigó, J. Harrow, T. J. Hubbard, S. G. Landt, S. Frietze, A. Abyzov, N. Addleman, R. P. Alexander, R. K. Auerbach, S. Balasubramanian, K. Bettinger, N. Bhardwaj, A. P. Boyle, A. R. Cao, P. Cayting, A. Charos, Y. Cheng, C. Cheng, C. Eastman, G. Euskirchen, J. D. Fleming, F. Grubert, L. Habegger, M. Hariharan, A. Harmanci, S. Iyengar, V. X. Jin, K. J. Karczewski, M. Kasowski, P. Lacroute, H. Lam, N. Lamarre-Vincent, J. Leng, J. Lian, M. Lindahl-Allen, R. Min, B. Miotto, H. Monahan, Z. Moqtaderi, X. J. Mu, H. O’Geen, Z. Ouyang, D. Patacsil, B. Pei, D. Raha, L. Ramirez, B. Reed, J. Rozowsky, A. Sboner, M. Shi, C. Sisu, T. Slifer, H. Witt, L. Wu, X. Xu, K.-K. Yan, X. Yang, K. Y. Yip, Z. Zhang, K. Struhl, S. M. Weissman, M. Gerstein, P. J. Farnham, M. Snyder, S. A. Tenenbaum, L. O. Penalva, F. Doyle, S. Karmakar, S. G. Landt, R. R. Bhanvadia, A. Choudhury, M. Domanus, L. Ma, J. Moran, D. Patacsil, T. Slifer, A. Victorsen, X. Yang, M. Snyder, K. P. White, T. Auer, L. Centanin, M. Eichenlaub, F. Gruhl, S. Heermann, B. Hoeckendorf, D. Inoue, T. Kellner, S. Kirchmaier, C. Mueller, R. Reinhardt, L. Schertel, S. Schneider, R. Sinn, B. Wittbrodt, J. Wittbrodt, Z. Weng, T. W. Whitfield, J. Wang, P. J. Collins, S. F. Aldred, N. D. Trinklein, E. C. Partridge, R. M. Myers, J. Dekker, G. Jain, B. R. Lajoie, A. Sanyal, G. Balasundaram, D. L. Bates, R. Byron, T. K. Canfield, M. J. Diegel, D. Dunn, A. K. Ebersol, T. Frum, K. Garg, E. Gist, R. S. Hansen, L. Boatman, E. Haugen, R. Humbert, G. Jain, A. K. Johnson, E. M. Johnson, T. V. Kutyavin, B. R. Lajoie, K. Lee, D. Lotakis, M. T. Maurano, S. J. Neph, F. V. Neri, E. D. Nguyen, H. Qu, A. P. Reynolds, V. Roach, E. Rynes, P. Sabo, M. E. Sanchez, R. S. Sandstrom, A. Sanyal, A. O. Shafer, A. B. Stergachis, S. Thomas, R. E. Thurman, B. Vernot, J. Vierstra, S. Vong, H. Wang, M. A. Weaver, Y. Yan, M. Zhang, J. M. Akey, M. Bender, M. O. Dorschner, M. Groudine, M. J. MacCoss, P. Navas, G. Stamatoyannopoulos, R. Kaul, J. Dekker, J. A. Stamatoyannopoulos, I. Dunham, K. Beal, A. Brazma, P. Flicek, J. Herrero, N. Johnson, D. Keefe, M. Lukk, N. M. Luscombe, D. Sobral, J. M. Vaquerizas, S. P. Wilder, S. Batzoglou, A. Sidow, N. Hussami, S. Kyriazopoulou-Panagiotopoulou, M. W. Libbrecht, M. A. Schaub, A. Kundaje, R. C. Hardison, W. Miller, B. Giardine, R. S. Harris, W. Wu, P. J. Bickel, B. Banfai, N. P. Boley, J. B. Brown, H. Huang, Q. Li, J. J. Li, W. S. Noble, J. A. Bilmes, O. J. Buske, M. M. Hoffman, A. D. Sahu, P. V. Kharchenko, P. J. Park, D. Baker, J. Taylor, Z. Weng, S. Iyer, X. Dong, M. Greven, X. Lin, J. Wang, H. S. Xi, J. Zhuang, M. Gerstein, R. P. Alexander, S. Balasubramanian, C. Cheng, A. Harmanci, L. Lochovsky, R. Min, X. J. Mu, J. Rozowsky, K.-K. Yan, K. Y. Yip, E. Birney, An integrated encyclopedia of DNA elements in the human genome. Nature. 489, 57-74 (2012). 
100. T. E. P. Consortium, J. E. Moore, M. J. Purcaro, H. E. Pratt, C. B. Epstein, N. Shoresh, J. Adrian, T. Kawli, C. A. Davis, A. Dobin, R. Kaul, J. Halow, E. L. V. Nostrand, P. Freese, D. U. Gorkin, Y. Shen, Y. He, M. Mackiewicz, F. Pauli-Behn, B. A. Williams, A. Mortazavi, C. A. Keller, X.-O. Zhang, S. I. Elhajjajy, J. Huey, D. E. Dickel, V. Snetkova, X. Wei, X. Wang, J. C. Rivera-Mulia, J. Rozowsky, J. Zhang, S. B. Chhetri, J. Zhang, A. Victorsen, K. P. White, A. Visel, G. W. Yeo, C. B. Burge, E. Lécuyer, D. M. Gilbert, J. Dekker, J. Rinn, E. M. Mendenhall, J. R. Ecker, M. Kellis, R. J. Klein, W. S. Noble, A. Kundaje, R. Guigó, P. J. Farnham, J. M. Cherry, R. M. Myers, B. Ren, B. R. Graveley, M. B. Gerstein, L. A. Pennacchio, M. P. Snyder, B. E. Bernstein, B. Wold, R. C. Hardison, T. R. Gingeras, J. A. Stamatoyannopoulos, Z. Weng, Expanded encyclopaedias of DNA elements in the human and mouse genomes. Nature. 583, 699-710 (2020).

101. A. Amiri, G. Coppola, S. Scuderi, F. Wu, T. Roychowdhury, F. Liu, S. Pochareddy, Y. Shin, A. Safi, L. Song, Y. Zhu, A. M. M. Sousa, P. Consortium, M. Gerstein, G. E. Crawford, N. Sestan, A. Abyzov, F. M. Vaccarino, Transcriptome and epigenome landscape of human cortical development modeled in organoids. Sci New York N Y. 362, eaat6720 (2018).

102. A. P. Boyle, E. L. Hong, M. Hariharan, Y. Cheng, M. A. Schaub, M. Kasowski, K. J. Karczewski, J. Park, B. C. Hitz, S. Weng, J. M. Cherry, M. Snyder, Annotation of functional variation in personal genomes using RegulomeDB. Genome Res. 22, 1790-1797 (2012).

103. A. Matsui, A. C. Yoshida, M. Kubota, M. Ogawa, T. Shimogori, Mouse $<$ em $>$ in Utero</em> Electroporation: Controlled Spatiotemporal Gene Transfection. J Vis Exp, 3024 (2011).

104. S. Hu, T. Yang, Y. Wang, Widespread labeling and genomic editing of the fetal central nervous system by in utero CRISPR AAV9-PHP.eB administration. Development. 148, dev195586 (2020).

105. J. C. Kwasnieski, I. Mogno, C. A. Myers, J. C. Corbo, B. A. Cohen, Complex effects of nucleotide variants in a mammalian cis-regulatory element. P Natl Acad Sci Usa. 109, 19498503 (2012).

106. M. Rabani, L. Pieper, G.-L. Chew, A. F. Schier, A Massively Parallel Reporter Assay of 3' UTR Sequences Identifies In Vivo Rules for mRNA Degradation. Mol Cell. 68, 1083-1094.e5 $30 \quad$ (2017).

107. M. D. Robinson, D. J. McCarthy, G. K. Smyth, edgeR: a Bioconductor package for differential expression analysis of digital gene expression data. Bioinformatics. 26, 139-140 (2009).

108. D. J. McCarthy, Y. Chen, G. K. Smyth, Differential expression analysis of multifactor RNA-Seq experiments with respect to biological variation. Nucleic Acids Res. 40, 4288-97 (2012). 
109. M. A. Rieger, D. M. King, H. Crosby, Y. Liu, B. A. Cohen, J. D. Dougherty, CLIP and Massively Parallel Functional Analysis of CELF6 Reveal a Role in Destabilizing Synaptic Gene mRNAs through Interaction with 3' UTR Elements. Cell Reports. 33, 108531 (2020).

110. O. Fornes, J. A. Castro-Mondragon, A. Khan, R. van der Lee, X. Zhang, P. A. Richmond, B. P. Modi, S. Correard, M. Gheorghe, D. Baranašić, W. Santana-Garcia, G. Tan, J. Chèneby, B. Ballester, F. Parcy, A. Sandelin, B. Lenhard, W. W. Wasserman, A. Mathelier, JASPAR 2020: update of the open-access database of transcription factor binding profiles. Nucleic Acids Res. 48, D87-D92 (2019).

111. A. Khan, O. Fornes, A. Stigliani, M. Gheorghe, J. A. Castro-Mondragon, R. van der Lee, A. Bessy, J. Chèneby, S. R. Kulkarni, G. Tan, D. Baranasic, D. J. Arenillas, A. Sandelin, K. Vandepoele, B. Lenhard, B. Ballester, W. W. Wasserman, F. Parcy, A. Mathelier, JASPAR 2018: update of the open-access database of transcription factor binding profiles and its web framework. Nucleic Acids Res. 46, D260-D266 (2017).

112. M. T. Weirauch, A. Yang, M. Albu, A. G. Cote, A. Montenegro-Montero, P. Drewe, H. S. Najafabadi, S. A. Lambert, I. Mann, K. Cook, H. Zheng, A. Goity, H. van Bakel, J.-C. Lozano, M. Galli, M. G. Lewsey, E. Huang, T. Mukherjee, X. Chen, J. S. Reece-Hoyes, S. Govindarajan, G. Shaulsky, A. J. M. Walhout, F.-Y. Bouget, G. Ratsch, L. F. Larrondo, J. R. Ecker, T. R. Hughes, Determination and inference of eukaryotic transcription factor sequence specificity. Cell. 158, 1431-1443 (2014).

113. A. Jolma, J. Yan, T. Whitington, J. Toivonen, K. R. Nitta, P. Rastas, E. Morgunova, M. Enge, M. Taipale, G. Wei, K. Palin, J. M. Vaquerizas, R. Vincentelli, N. M. Luscombe, T. R. Hughes, P. Lemaire, E. Ukkonen, T. Kivioja, J. Taipale, DNA-Binding Specificities of Human Transcription Factors. Cell. 152, 327-339 (2013).

114. D. E. Newburger, M. L. Bulyk, UniPROBE: an online database of protein binding microarray data on protein-DNA interactions. Nucleic Acids Res. 37, D77-D82 (2009).

115. I. V. Kulakovskiy, I. E. Vorontsov, I. S. Yevshin, R. N. Sharipov, A. D. Fedorova, E. I. Rumynskiy, Y. A. Medvedeva, A. Magana-Mora, V. B. Bajic, D. A. Papatsenko, F. A. Kolpakov, V. J. Makeev, HOCOMOCO: towards a complete collection of transcription factor binding models for human and mouse via large-scale ChIP-Seq analysis. Nucleic Acids Res. 46, D252-D259 (2018). 